\title{
A comprehensive overview of the diagnosis and treatment of hypertension based on the latest hypertension guidelines
}

\author{
Seyed Ali Moezi Bady ${ }^{\left(\mathbb{D}{ }^{1,2}\right.}$, Toba Kazemi ${ }^{(1 *}{ }^{*}$, Hamidreza Mashreghi-Moghadam ${ }^{1}{ }^{1,2}$, Nahid \\ Azdaki ${ }^{1,2}$, Neda Partovi ${ }^{1,2}$, Nazanin Hanafi Bojd ${ }^{1,2}$, Mohammad Yousof Qoddusi ${ }^{1,2}$, \\ Hassan Dianat ${ }^{10}{ }^{1,2}$, Shima Jafari ${ }^{1}{ }^{1,3}$
}

\begin{abstract}
In recent years, non-communicable diseases (NCDs) have accounted for about $70 \%$ of the world's deaths. The most common NCDs are cardiovascular disease, cancer, diabetes mellitus, and chronic respiratory diseases. These diseases have four common risk factors, including inadequate physical activity, unhealthy diet, smoking, and excessive alcohol consumption. Cardiovascular diseases, despite their high prevalence, are the most preventable chronic diseases. The most common risk factor for cardiovascular disease is high blood pressure, which can be prevented if it is diagnosed and controlled carefully. Recent guidelines have changed the methods of blood pressure measurement, definition, and treatments. Recently, more emphasis has been placed on Out-of-Office Blood Pressure Measurement. Therefore, it is necessary to consider the methods of measuring blood pressure at home and 24-hour Holter blood pressure monitoring, as well as understanding its standards. The use of automatic arm sphygmomanometers to measure blood pressure is more acceptable than manual ones (mercury or Aneroid). The most accepted definitions of hypertension are $\mathrm{BP} \geq 140 / 90 \mathrm{~mm} \mathrm{Hg}$ in the clinic, the average blood pressure at home $\geq 135 / 85 \mathrm{~mm} \mathrm{Hg}$, and the average blood pressure in 24-hour Holter monitoring $\geq 130 / 80 \mathrm{~mm} \mathrm{Hg}$. Proper treatment of hypertension by changing lifestyle and proper medication therapy can control blood pressure and prevent serious complications. Today, the use of combination drugs, especially a single pill in a single dose, has been emphasized. This study aimed to review the most recent hypertension treatment protocols based on the guidelines of the American Heart Association (AHA 2017), the European Society of Cardiology (ESC 2018), the British Heart Association (NICE 2019), and the International Society of Hypertension (ISH 2020). Furthermore, this study attempted to assess the symptoms, complications, methods of diagnosing, definitions, as well as pharmacological and non-pharmacological treatments of hypertension.
\end{abstract}

Keywords: Cardiovascular disease, COVID-19, Diagnose, Guideline, Hypertension, Treatment

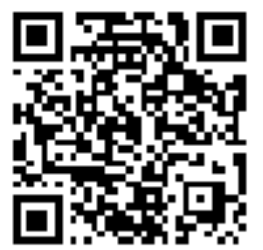

Citation: Moezi Bady SA, Kazemi T, Mashreghi-Moghadam HR, Azdaki N, Partovi N, Hanafi Bojd N, Qoddusi MY, Dianat H, Jafari Sh. [A comprehensive overview of the diagnosis and treatment of hypertension based on the latest Highbine Guidelines]. J Birjand Univ Med Sci. 2021; 28(3): 194-221. [Persian]

DOI http://doi.org/10.32592/JBirjandUnivMedSci.2021.28.3.100

Received: January 30, 2021

Accepted: August 9, 2021

${ }^{1}$ Cardiovascular Diseases Research Center, Birjand University of Medical Sciences, Birjand, Iran

${ }^{2}$ Razi Clinical Research Development Unit (RCRDU), Birjand University of Medical Sciences, Birjand, Iran

${ }^{3}$ Department of Clinical Pharmacy, School of Pharmacy, Birjand University of Medical Sciences, Birjand, Iran

* Corresponding author: Cardiovascular Diseases Research Center, Birjand University of Medical Sciences, Birjand, Iran

Tel: +985631626460

Fax: +985632234717

E-mail: drtooba.kazemi@gmail.com

194 


\title{
مرورى جامع بر تشخيص و درمان فشارخون بالا بر اساس آخرين دستور العملهاى بالينى

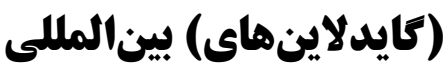

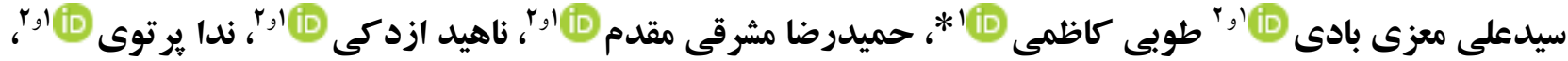

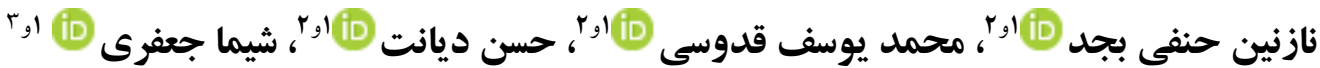

\section{جكيده}

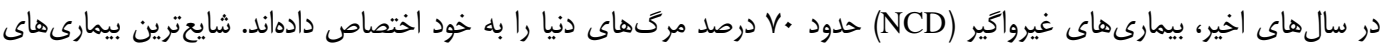

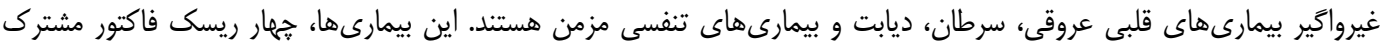

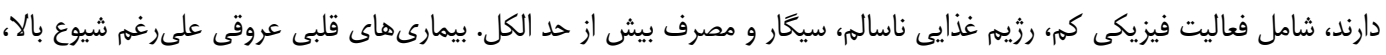

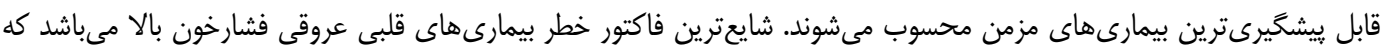

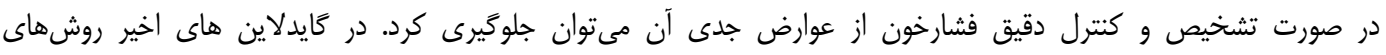

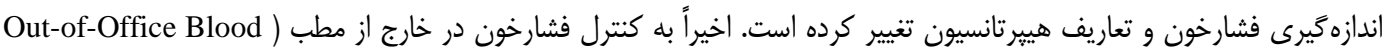
Pressure Measuremen

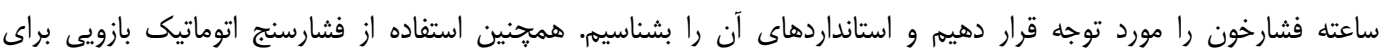

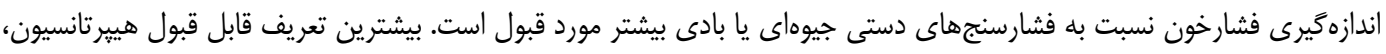

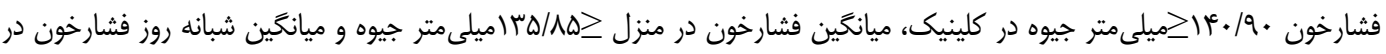

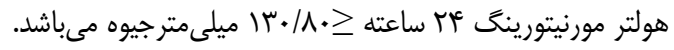

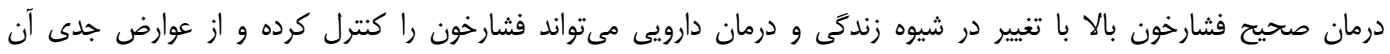

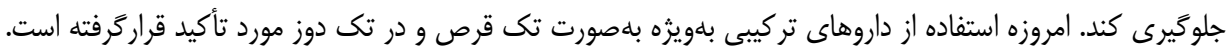

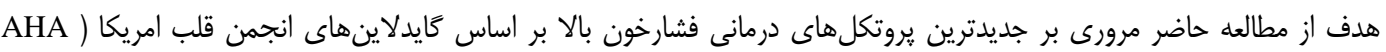

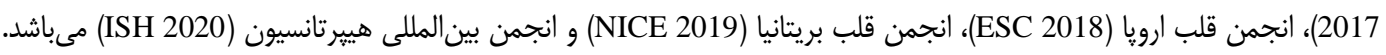

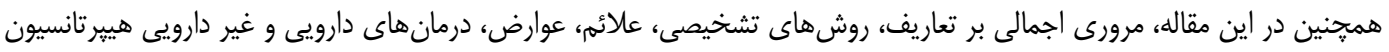
خواهيم داشت.

$$
\text { ورازهاى كليدى: بيمارى هاى قلبى عروقى، كرونا، تشخيص، كايدلاين، فشارخون بالا، درمان }
$$

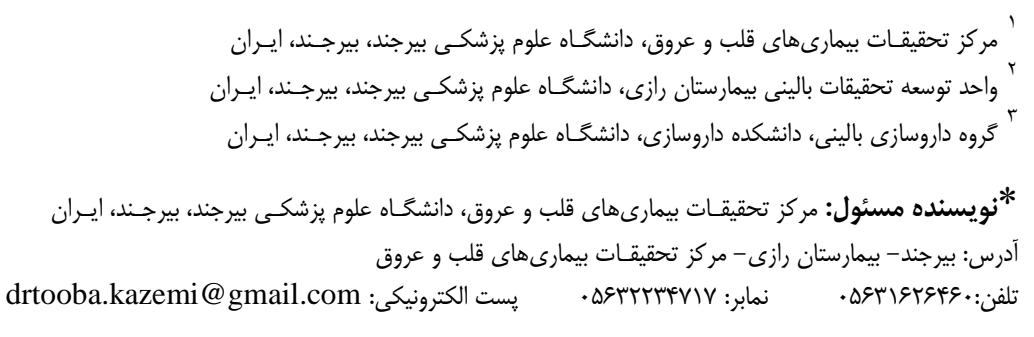




\section{تعريف فشارخون بالا (هيير تانسيون)}

مقدمه

در مورد تعريف فشارخون بالا و حدّى از فشار كه به عنوان هييرتانسيون در نظر كرفته شود، كايدلاين قلب امريكا در سال سال

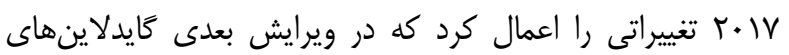

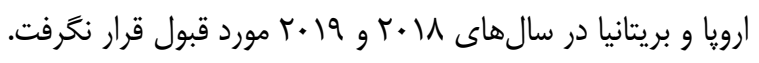
در جدول ا مقايسه بين تعريف فشارخون بالا و تقسيهبندى آن

$$
\text { بر اساس آخرين كايدلاينها آمده است. }
$$

همانطور كه مشاهده مىشود بر اساس كايدلاين

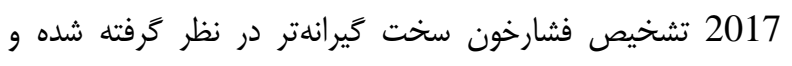

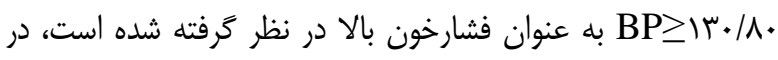

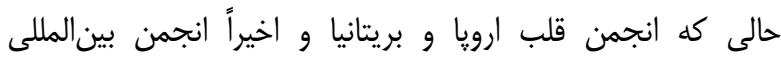

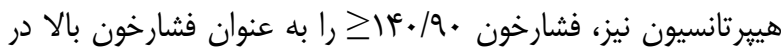
نظر كرفتهاند.

در جدول r تعريف هييرتانسيون بر اساس روشهاى مختلف ردفة

$$
\text { اندازميرى فشارخون آمده است. }
$$

همانطور كه مشاهده مى شود ميانگين فشارخون در منزل

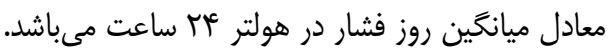
نكتته: ييشنهاد ما استفاده از كايدلاينهاى ISH و

$$
\text { تعاريف هييرتانسيون مىباشد (جداول ( و r). }
$$

از جمله شايعترين بيمارىهاى غيرواگير مىتوان به بيمارىهاى

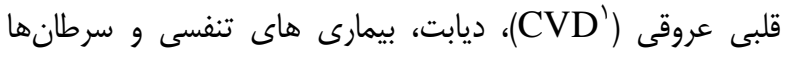

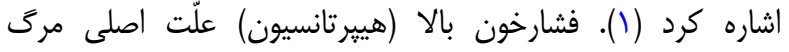
زودرس و ناتوانى در سراسر جهان است (1). هيبرتانسيون مهرترين عامل خطر بيمارى عروق كرونر (CAD)، سكته مغزى (stroke)،

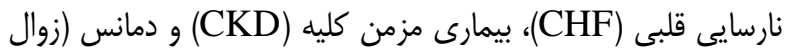

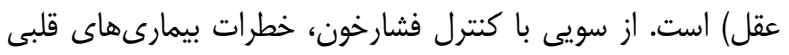

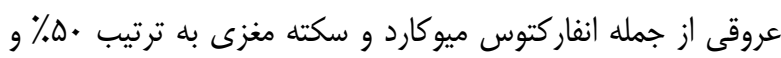

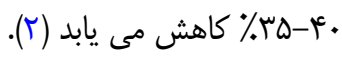

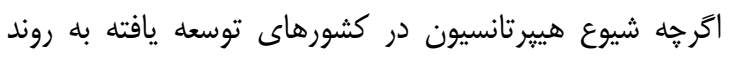
ثابتى رسيده است؛ اما در كشورهاى در حال توسعه هنوز در حال

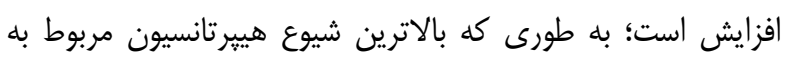

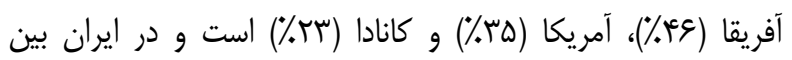

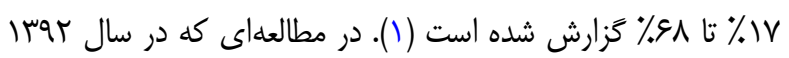

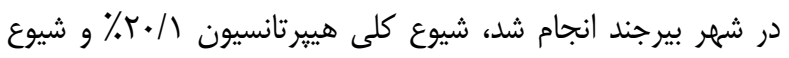

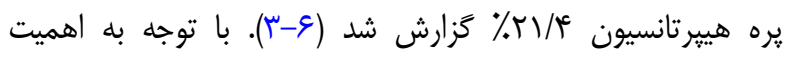

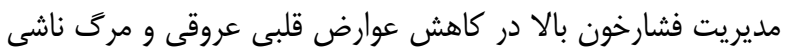

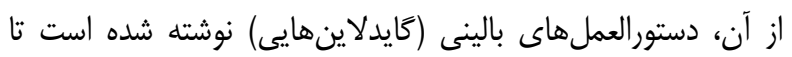

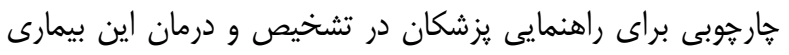
فراهم شود. اخرجه بين اين دستورالعمل ها تفاوت هايى وجود داردي؛ امّا همبوشانى هاى زيادى نيز دارند. از سويى شايعترين علت مراجعه به مطب، كنترل فشارخون است؛ لذا لازم است يزشكان با آخرين دستورالعملهاى (يروتكل) درمانى آشنا شوند. هدف از اين مطالعه مرورى بر درمانهاى جديد بلديد يرفشارى خون با استفاده از دستورالعملهاى انجمن قلب امريكا

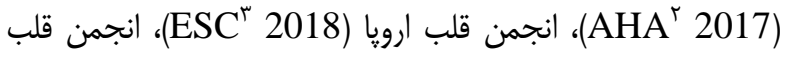
بريتانيا (NICE 2019) و انجمن بين المللى هييرتانسيون(

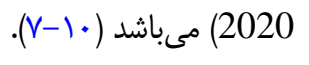

${ }^{1}$ Cardiovascular disease

${ }^{2}$ American Heart Association

${ }^{3}$ European Society of Cardiology

${ }^{4}$ National Institute for Health and Care Excellence

${ }^{5}$ International Society of Hypertension 
جدول ا - مقايسه تعاريف هيير تانسيون در تَايدلاينهاى مختلف

\begin{tabular}{|c|c|c|c|c|}
\hline ESC, ISH, NICE & AHA & (ميلىمتر جيوه) & \multicolumn{2}{|c|}{ (ميلى ستر جيوها } \\
\hline ايده آل & نرمال & $<\Lambda$. & \multicolumn{2}{|c|}{$g<1 r}$. \\
\hline 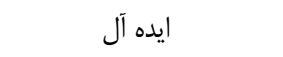 & بالا(elevated) & $<\wedge$. & 9 & $1 r \cdot-14 a$ \\
\hline بالاتر از حد نرمال & هيير تانسيون كريد I & $\wedge \cdot-19$ & يا & q \\
\hline هيير تانسيون كريدا I & هيير تانسيون گريد & $9 \cdot-99$ & يا & $14 \cdot-10 q$ \\
\hline هيير تانسيون كريداد & هيير تانسيون گريد & $1 . .-1.9$ & يا & $19 \cdot-119$ \\
\hline هيير تانسيون گر يدادIII & هيير تانسيون كريد & $\geq 11$. & يا & $\geq 1 \Lambda$. \\
\hline
\end{tabular}

جدول r- مقايسه تعاريف هيير تانسيون در كايدلاينهاى مختلف بر اساس روشهاى مختلف اندازهَيرى

\begin{tabular}{|c|c|c|c|c|c|}
\hline \multicolumn{2}{|c|}{ ISH ،ESC } & \multicolumn{2}{|c|}{ AHA } & & روش اندازهيرى فشار خون \\
\hline دياستوليك & سيستوليك & دياستوليك & سيستوليك & & \\
\hline$\geq q$. & $\geq 16$ & $\geq \wedge$ & $\geq 1 r$ & & فشارخون كلينيك يا مطب \\
\hline$\geq \wedge \Delta$ & $\geq 1 \% \Delta$ & $\geq \wedge$ & $\geq 1 \%$ & ] [ميانكين روز & هولتر فشارخون ع ساعت \\
\hline$\geq v$. & $\geq 1 \%$ & $\geq 9 \Delta$ & $\geq 11$. & ل ميانحين شب & \\
\hline$\geq 1$. & $\geq 1 \%$. & $\geq \vee \Delta$ & $\geq I T \Delta$ & |ميانكَين זب ساعته & \\
\hline$\geq \wedge \Delta$ & $\geq$ Ira & $\geq \wedge$. & $\geq 1 r$. & & ميانكين فشارخون در منزل \\
\hline
\end{tabular}

در افراد برادى كارد، اگر سرعت تخليه كاف بالا باشد، اولين صدا

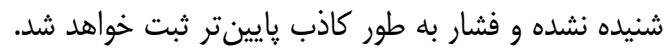

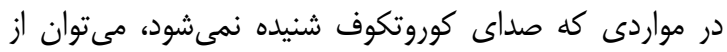

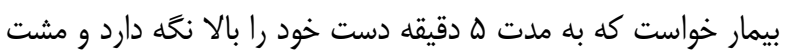

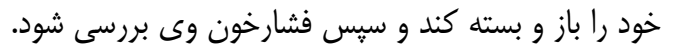

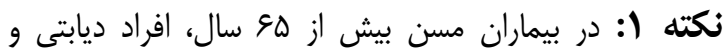
بيمارانى كه داروهاى كاهنده فشارخون مصرف مى كنند و علائمى

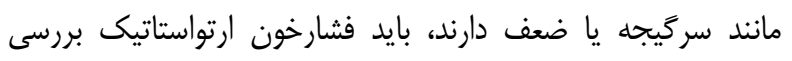

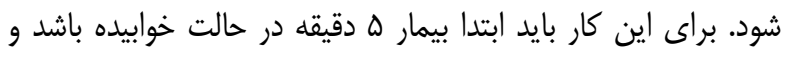
فشارخون وى اندازيّيرى شود، سبس ايستاده و فشارخون وى

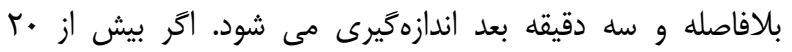
ميلىمتر جيوه افت فشارخون داشته باشد، دجار افت فشارخون وضعيتى يا هييوتانسيون ارتواستاتيك هست (II).

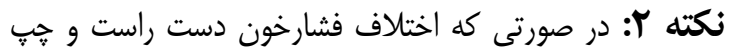
بيشتر از ها ميلىمتر جيوه باشد بايد به فكر عللى مانند آترواسكلرزو شريانى، تنكى شريان ساب كلاوين يا كواركتاسيون أئورت باشيه

\section{اندازهيَى فشارخون به روش استاندارد استفاده از فنشارسنج ديجيتال}

روش ارجح در حال حاضر استفاده از فشارسنج ديجيتال بازويى

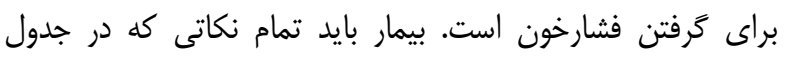

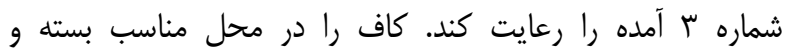

$$
\text { فشارخون را ثبت كند (جدول سا). }
$$

\section{استفاده از فثارسنج بازويى دستى ليث}

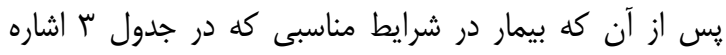

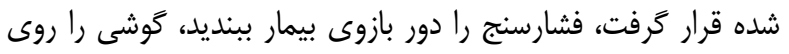

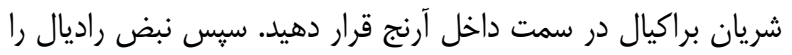

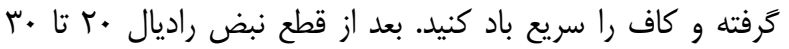

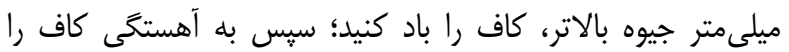

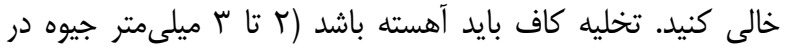
ثانيه). حال نبض را رها كرده و به صداهاى كوروتكوف گوش كنيد. اولين صدايى كه شنيديد به عنوان فشار سيستولى و زمان قطع صدا

$$
\text { به عنوان فشار دياستول در نظر كرفته مىشود. }
$$
تخليه آهسته كاف از اهميت زيادى برخوردار است. بلهخصوص دئرس 


\section{جدول س- نكات لازم براى اندازهَيرى فشارخون}

- - حداقل بايد ه دقيقه در محيط با دماى مناسب و آرام روى صندلى نشسته باشد.

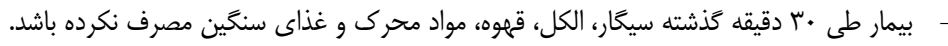

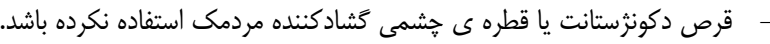

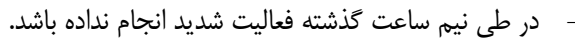

شرايط بيمار

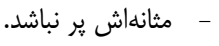

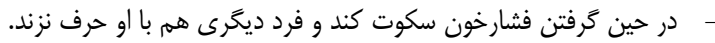

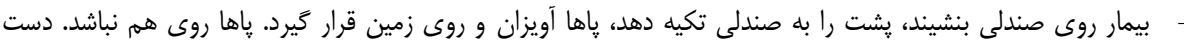

روى سطح صاف و در سطح قلب قرار گيرد.

وضعيت بيمار (تصوير ()

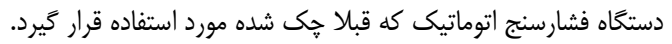

دستخاه اندازهَيرى

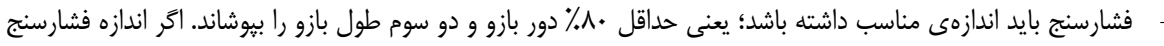

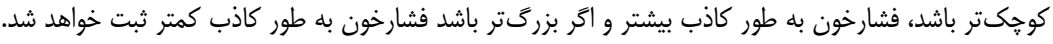

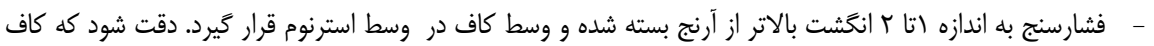

كاف فشارسنج

فشارسنج خيلى شُل يا خيلى محكم بسته نشود.

در هر ويزيت ب دفعه به فاصله ادقيقه فشارخون اندازهيرى شود. ميانگين دو دفعه آخر محاسبه شود. اخر فشارخون دفعه

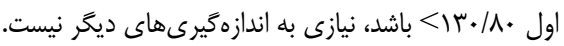

روش اندازهَيرى

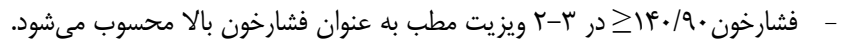

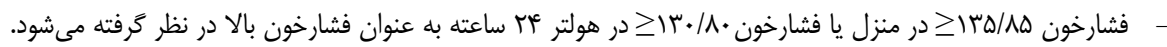

تفسير بر اساس ESC و ISH

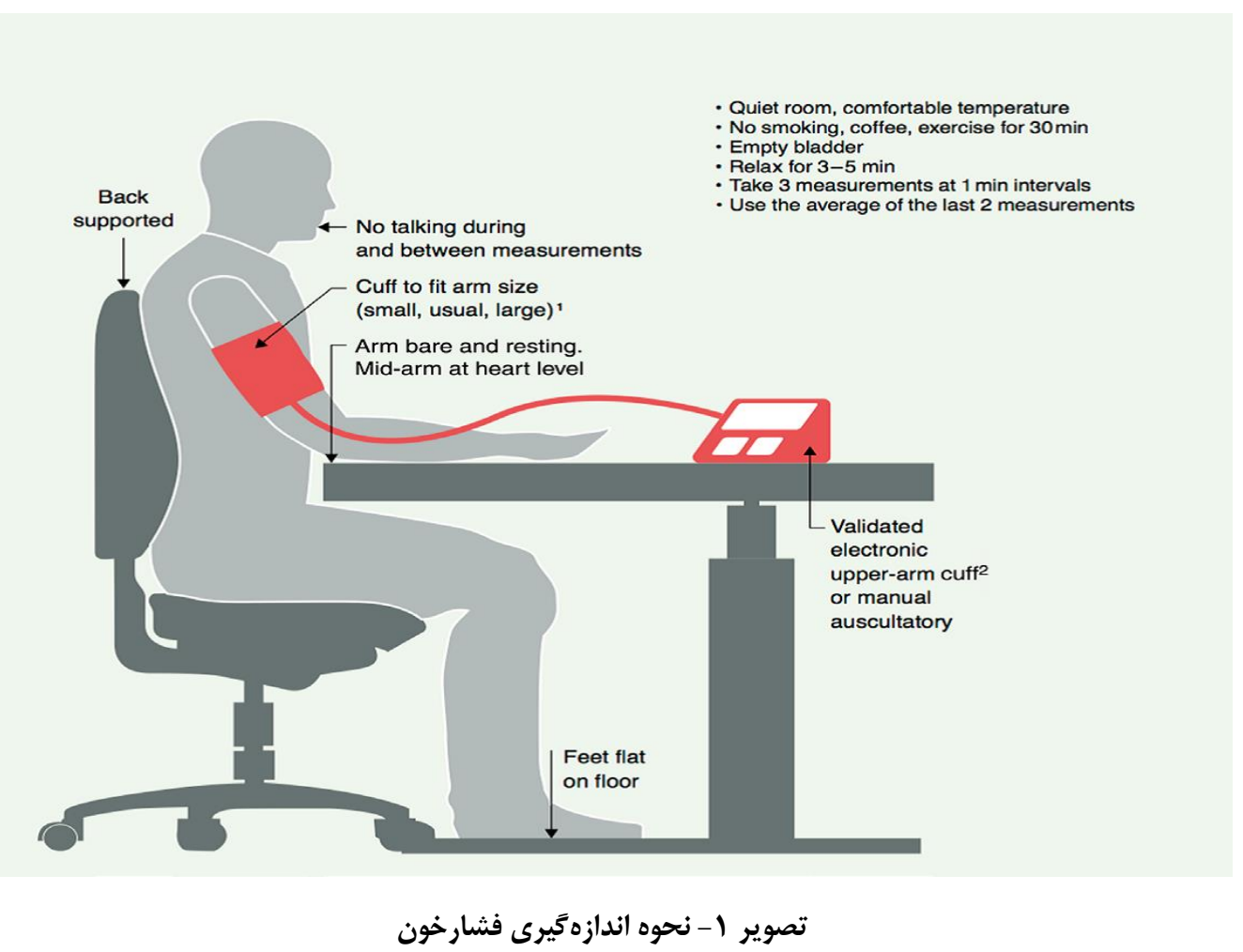


ميانگين دو نوبت آخر محاسبه شود. سبِ فشار روز اول كه ممكن است به طور كاذب بالا باشد، حذف تردد و ميانخين فشارخون ثبت شده به عنوان HBPM استفاده مى كردد. بايد دستكاه فشارسنج و سايز كاف ابتدا در مطب توسط يزشك تأيبد

نتايج اندازهيرى فشارخون در منزل (HBPM) به ميانگَين

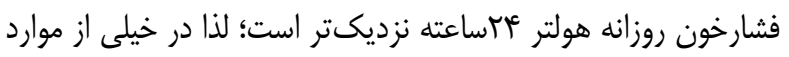
از اندازمكيرى فشارخون در منزل براى تشخيص هييرتانسيون

استفاده مى شود (س) (1).

نكته: در صورتى كه بيمار سابقه هييرتانسيون و مصرف دارو دارد، فشارخون نيم ساعت قبل از مصرف دارو كرفته شود؛ همجنين

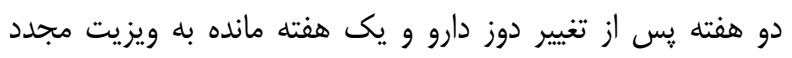

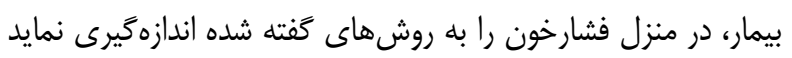
و براى تصميم گيرى درمانى به يزشك ارائه نمايد. نكته: در بيماران با ريته AF و اكسترا سيستولهاى فراوان دئن روش اتوماتيك ممكن است مناسب نباشد. در بيمارانى هم كه وسواس شديد براى كرفتن فشارخون دارند، اين روش مناسب نيست.

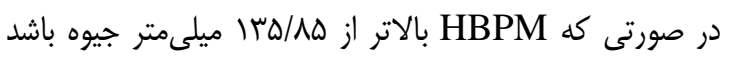

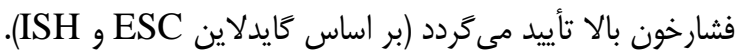
Office Blood ( اندازهيرى فشارخون در مطب يا كلينيك

(Pressure Measurement به طور معمول فشارخون در مطب اندازهگيرى مىشود. در

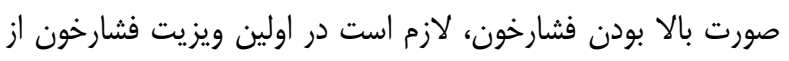

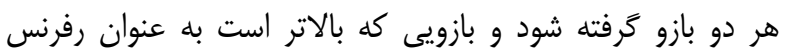
اندازمخيرى هاى بعدى استفاده شود.

اندازهيرى فشارخون در مطب به دو روش قابل انجام است:

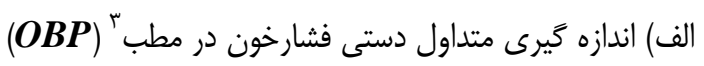
در صورت استفاده از فشارسنج دستى در مطب، فشارخون بايد

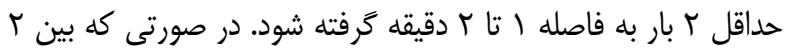
بار اندازمخيرى بيشتر از هـ ميلىمتر جيوه اختلاف باشد، بايد مجدداً

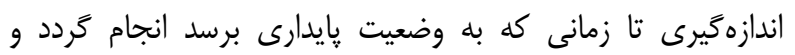

${ }^{3}$ Conventional Office BP (OBP)
شيوههاى مختلف اندازهَيرى فثار خون روشهاى مختلفى براى اندازهكيرى فشارخون استفاده مى مشود

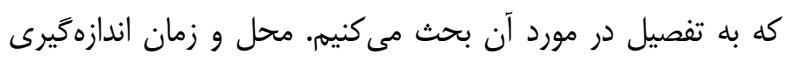
در تعريف فشارخون و تشخيص آن مؤثر است.

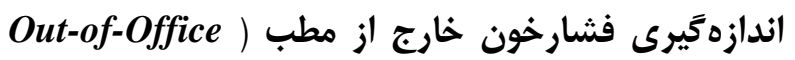
(Blood Pressure Measurement امروزه تأكيد بر كنترل فشارخون در خارج از مطب شده است. اين امر باعث كاهش فشارخون رويوش سفيد شده است.

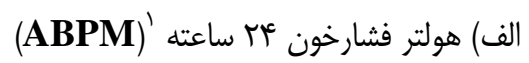

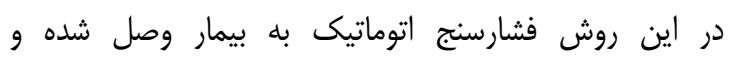

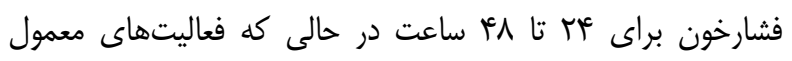

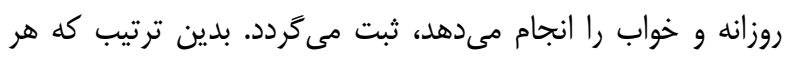

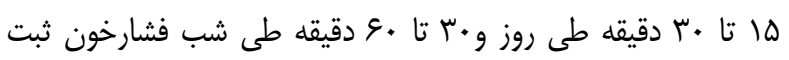

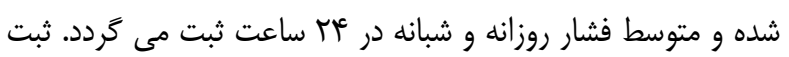

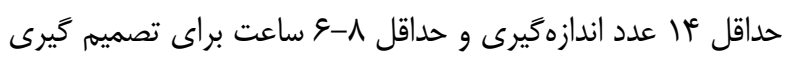

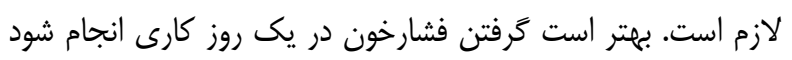

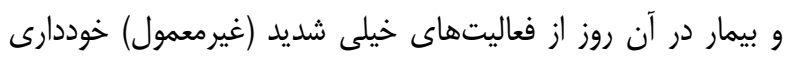
نمايد. ABPM روش استاندارد تشخيص هيبرتانسيون است. تنها روشى كه وضعيت فنشارخون در شب را نشان مىدهد و نيز براى

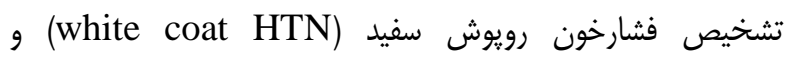
فشارخون ماسكه (masked HTN) از آن استفاده مىشود؛ امّا اين روش كران بوده و بلهراحتى در دسترس نمى ماشدا.

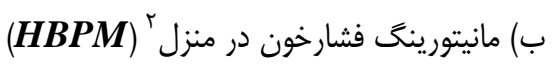

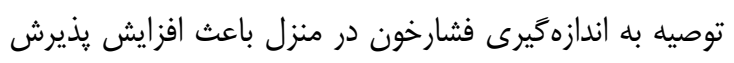
بيمار براى درمان مىشود. توصيه مىشود كه با رعايت شرايط لازم (مطابق جدول r) فشارخون اندازمكيرى شود.

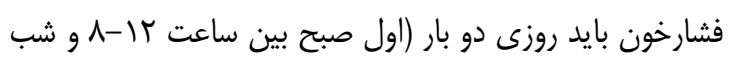

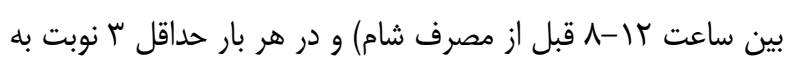

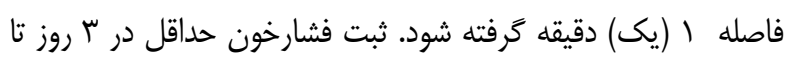

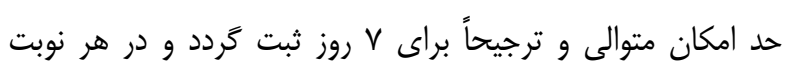

\footnotetext{
${ }^{1}$ Ambulatory BP Monitoring (ABPM)

${ }^{2}$ Home BP Monitoring (HBPM)
} 
يرفشارى خون، بايد از ساير روشها استفاده كرد (تصوير r). همان

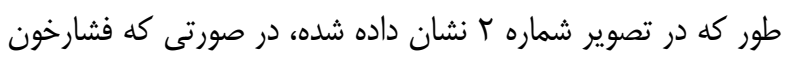

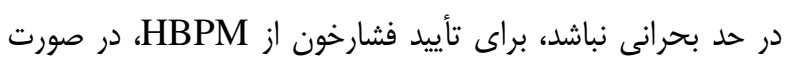

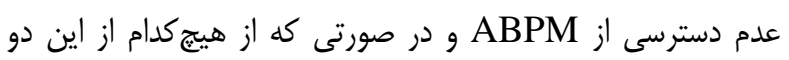

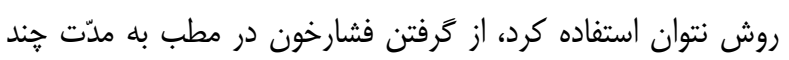
روز براى تأييد فشارخون مى توان استفاده كرد.

\section{تشخخيص}

از آنجايى كه تشخيص هيبرتانسيون از اهميت قابل توجهى برخوردار است؛ لذا بر اساس Up to Date و كامل تشخيصى هييرتانسيون در بالغين به صورت الكوريتم نشان

$$
\text { داده شده است (تصوير r)(•). }
$$

همان طور كه در الخَوريتم مشاهده مىشود در صورتى كه الته

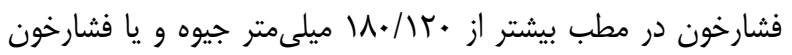

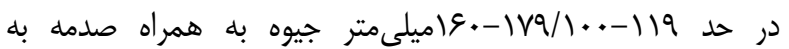
اركانهاى هدف تشخيص فشارخون بالا حتمى است؛ امّا در مقادير

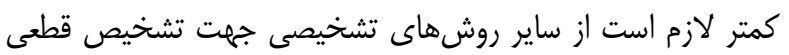
فشارخون استفاده گردد.

\section{علت هيير تانسيون}

هيبرتانسيون به دو دسته اوليه ( Primary,Essential (Idiopathic,

\section{هيبر تانسيون اوليه}

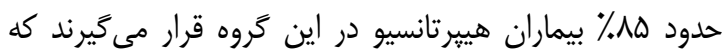
هيج علّت واضح و مشخصى براى ايجاد فشارخون بالا در بيمار يافت

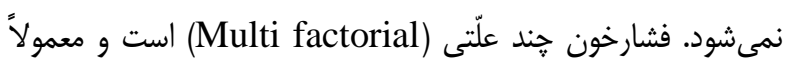
در يك زمينه زنتيك، فاكتورهاى محيطى دست به دست هم دارئ داده و باعث ايجاد فشارخون بالا مى شود. در اين بيماران معمولا فشارخون

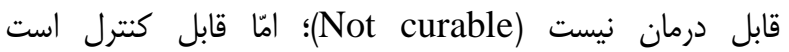
و بيمار بايد براى كتترل فشارخون بdطور منظم (Controllable)

$$
\text { رزيهم غذايى را رعايت كرده يا دارو مصرف نمايد. }
$$

سيس متوسط آخرين دو نوبت فشارخون محاسبه كَردد.

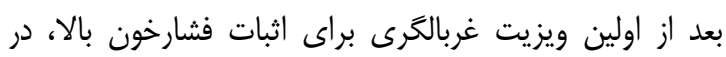

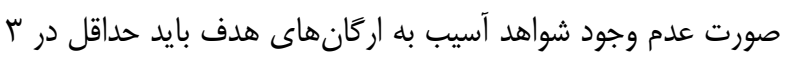

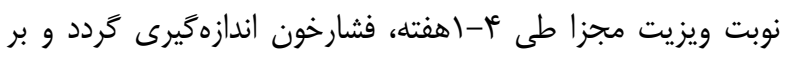
اساس ميانكين ب نوبت ويزيت تصميم كيرى شود. ب) اندازمخيرى اتوماتيك فشارخون در مطب ' (AOBP

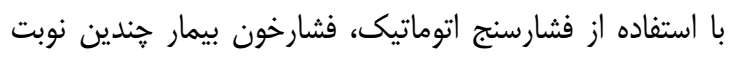
يشت سر هم بعد از قرار خرفتن وى در اتاق معاينه و بلدون وجود

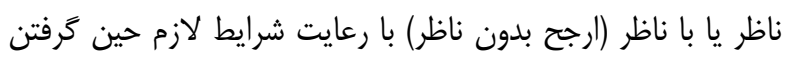

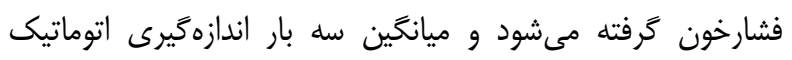
يشت سر هم به فاصله يك دقيقه توسط خود دستخاه به عنوان عدد فشارخون ثبت مى كردد. دستخاههاى AOBP از نظر تعداد دفعات

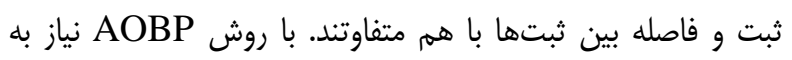

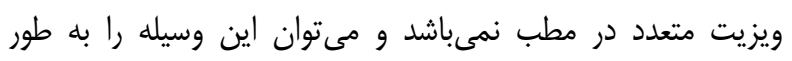

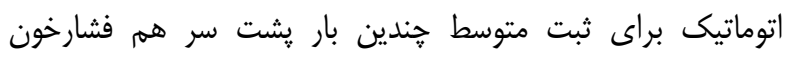
تنظيم كرد. با اين روش واكنش به رويوش سفيد به حداقل مىرسد و به فشارخون در منزل (HBPM) و هولتر مانيتورينگ أب ساعته

$$
\text { فشارخون نزديكتر است (f) (1). }
$$

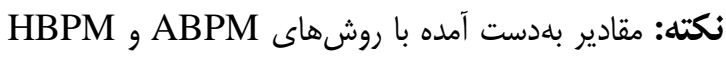
به اندازه • 1- ه ميلىمتر جيوه نسبت به اندازمگيرى مطب پائينتر

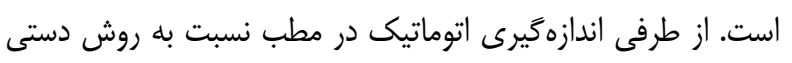

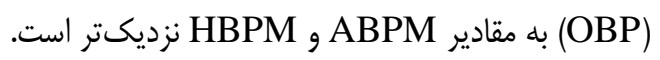

\section{جمعبندى نكات مربوط بله تشخيص فثشارخون و روشهاى اندازهكيرى آن}

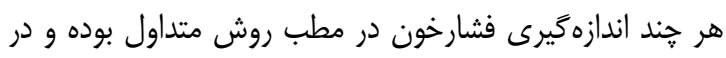

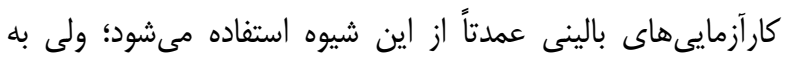

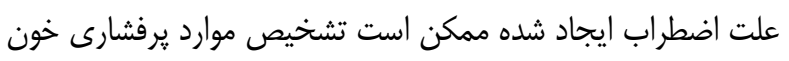

بيشتر از معمول كذاشته شود (Over Diagnosis).

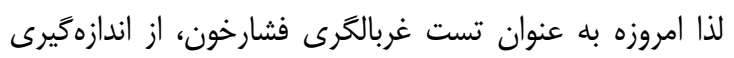

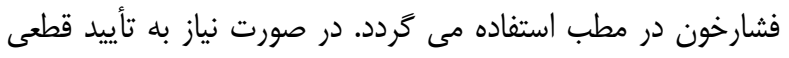

\footnotetext{
${ }^{1}$ Automated Office BP (AOBP)
} 
ديخر است) و عوامل زنتيكى (عوامل زنتيكى تقريباً • ب درصد از تغييرات فشارخون در جوامع مختلف را به خود اختصاص مىدهد)، نزاد (فشارخون بالا در نزاد سياه يوست شايعتر، شديدتر و در سنين

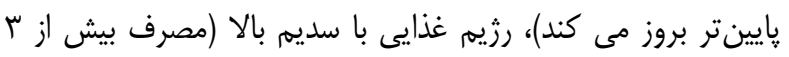
كرم نمك در روز)، مصرف زياد الكل، عدم فعاليت فيزيكى مناسب.
عوامل خطر هييرتانسيون اوليه عبارتند از: سن (افزايش سن با افزايش فشارخون بهخصوص فشارخون سيستوليك رابطه دارد و

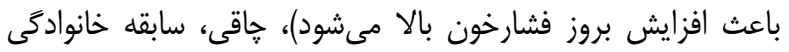
(شانس هييرتانسيون در افرادى كه يكى يا دو عضو از اعضاى

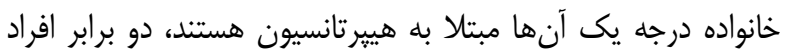

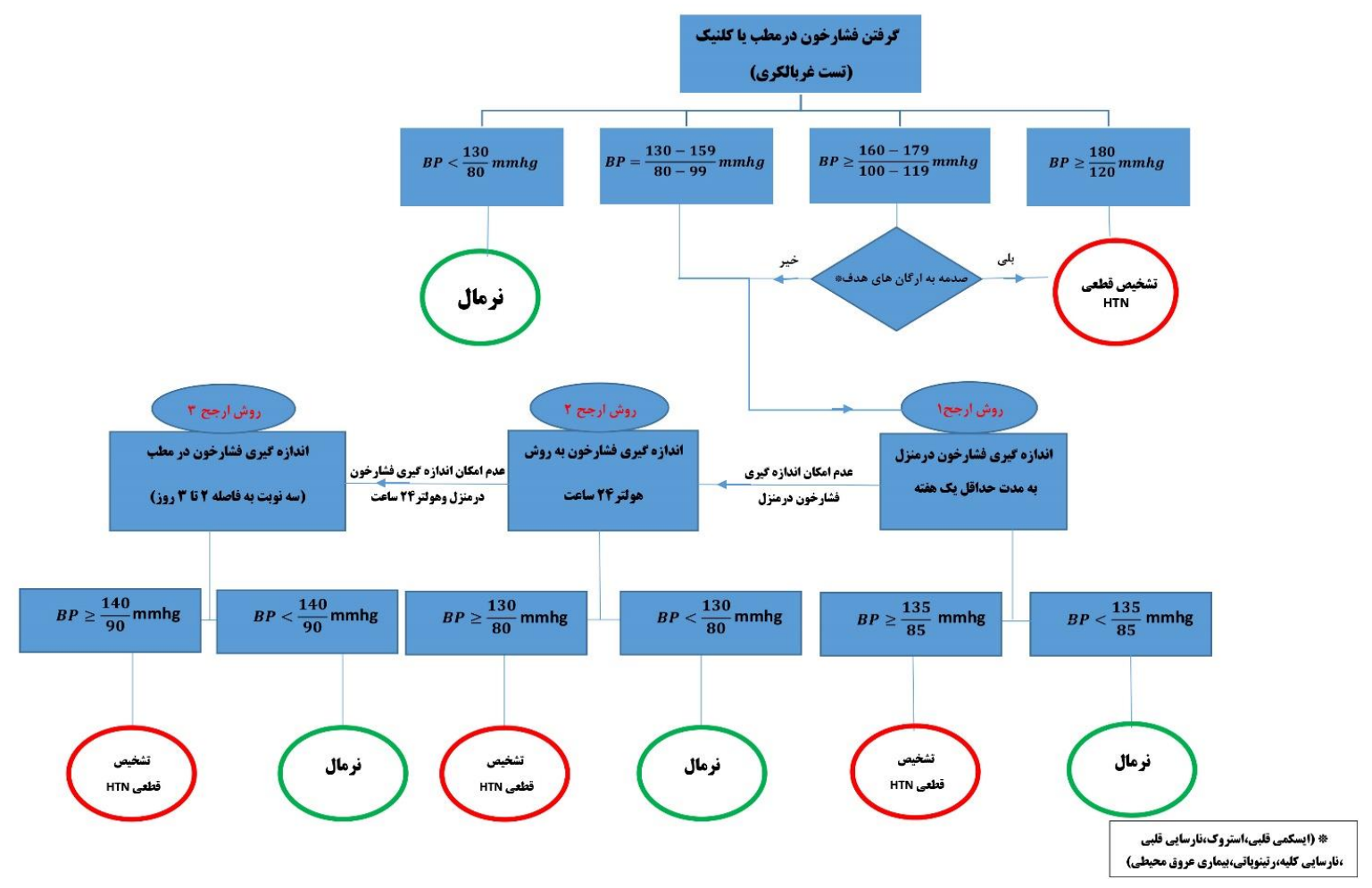

تصوير r- الكوريتم تشخيص هيبر تانسيون در بالغين براساس Up to Date و 2020 ISH

\section{هيبر تانسيون ثانويه}

در حدود • ا تا ها ٪ بيماران هيبر تانسيو، مىتوان عامل واضح و

مشخص براى ايجاد فشارخون ييدا كرد. تشخيص فشارخون ثانويه بسيار مهم است؛ هرا كه مواردى از اين بيمارى را مىتوان بلطور كامل درمان كرد (curable)؛ به عنوان مثال برداشتن توده آدرنال در فئوكروموسيتوم يا رفع تنكى در كواركتاسيون أئورت. از طرفى ممكن است در مواردى نياز به داروى اختصاصى باشد؛ به عنوان مثال در فشارخون ثانويه مصرف قرص ضد باردارى (OCP) استفاده

$$
\text { از داروى آنتى آلدوسترون كمك كنتده است. }
$$

هييرتانسيون ثانوى به علل مختلف دارويى و نيز در زمينه

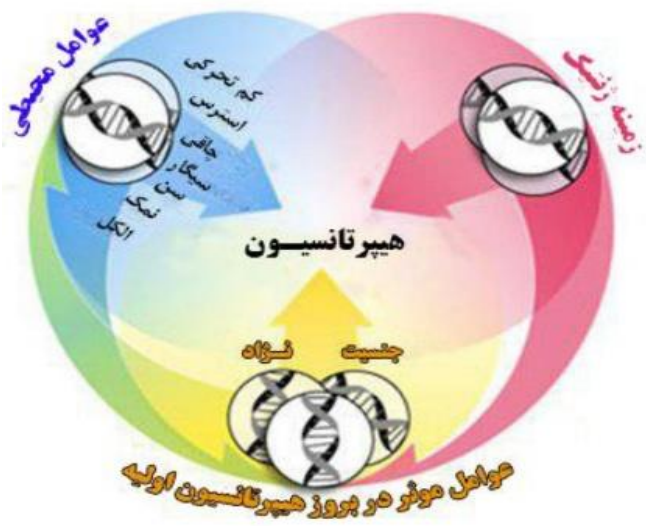

تصوير بـ- عوامل مؤثر در بروز هيير تانسيون اوليه 
جدول F - علل هيبر تانسيون ثانويه

\begin{tabular}{|c|c|c|}
\hline بيمارى كليوى إنسارادى كليه، كيست كليه (كليه يلى كيستيك)، تومورهاى كليوى (تومور ترشح كننده رنين)، & $\% \Delta-1$. & بيمارىهاى كليوى \\
\hline آترواسكلروتيك، ديسٍلازى فيبروموسكولر & $\% 1-1$ & بيمارى عروق كليه (رنوواسكولار) \\
\hline-- & $<\%$ & كواركتاسيون آئورت \\
\hline-- & $\% \Delta-1$ & يره اكلاميسى / اكلامِسى \\
\hline يُّيكى نوريت (يورفيرى حاد، مسمويت با سرب)، افزايش حاد فشار داخل مغزى، ديس اتونومى فاميلى، & & نوروزنيك \\
\hline سندير كوشينگ، آلدوسترونيسم اوليه، هييوتيروئيدى، هيير تيروئيدى، هيبر كلسمى، هييرياراتيروئيدى، آكرومكالى، & $\% \Delta-10$ & بيمارى هاى آندوكرين \\
\hline-- & $\% \Delta-1$ & آينه انسدادى خواب \\
\hline به طور كامل در جدوله آمده است. & & داروها \\
\hline
\end{tabular}

جدول هـ - داروهاى افزايش دهنده فشارخون

\begin{tabular}{|c|c|}
\hline 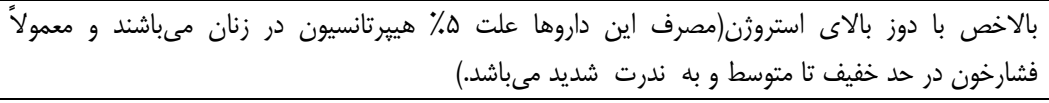 & 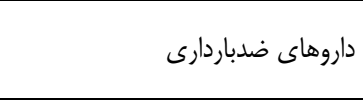 \\
\hline Sibutramine،Liquorice.Phenylpropanolamine & داروهاى كاهش دهنده وزن \\
\hline فنيل افرين هيدروكلرايد، نفازولين هيدروكلرايد و ... & داروهاى ضد احتقان \\
\hline مفتامين، كوكائين و اكستازى( اين مواد معمولاً باعث افزايش ناگمانى فشارخون مىشوند.) & داروهاى محرى \\
\hline سيكلوسيورين، تاكروليموس & داروهاى ايمونوسايرسيو \\
\hline هيدروكورتيزون، يردنيزولون،تر يامسينولون، دكزامتازون & داروهاى كورتيكواستروئيد \\
\hline 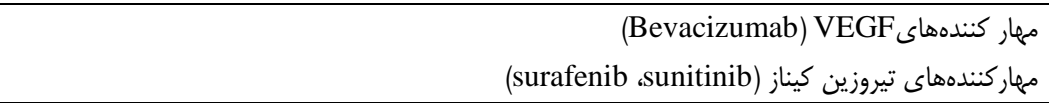 & داروهاى آنتى آنثيوزنيك ضد سرطان \\
\hline سلكو كسيب، نايروكسن، ايبويروفن، ملوكسيكام & $\begin{array}{r}\text { داروهاى ضدالتهاب غيراستروئيدى } \\
\text { (NSAIDS) }\end{array}$ \\
\hline مصرف روزانه آن ريسك فشارخون راحدودا ه.ا برابرمى كند. & استامينوفن \\
\hline آلكالوئيدهاى ارَّوت، كَياه علف خاى، شيرين بيان، آلكالوئيدهاى افدرا & 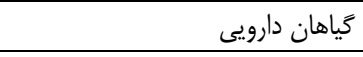 \\
\hline استروئيدهاى آنابوليك، اريترويوئيتين، ونلافاكسين، بويروييون & ساير داروها \\
\hline
\end{tabular}

صبحگاهى و در ناحيه يس سر است)، سرگيجه، وز وزگوش،

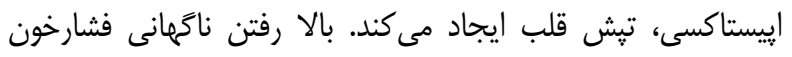
مىتواند در بعضى از بيماران سردرد خيلى شديد (در كل سر بدون

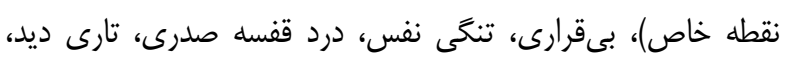

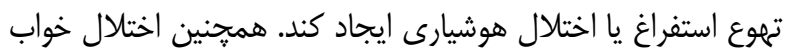

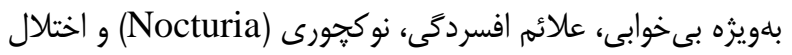

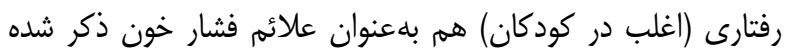

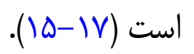

نكته: با توجه به اهميت هييرتانسيون ثانويه در هر بيمار هيبرتانسيو كه براى اولين بار ويزيت مىشود، بايد به فكر رد رد علل

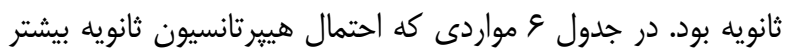
است ذكر شده است.

\section{علائم هيير تانسيون}

فشارخون بالا اغلب علامتى ايجاد نمى كند. به همين علّت

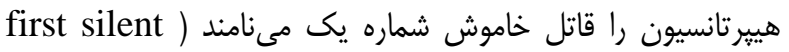
killer 


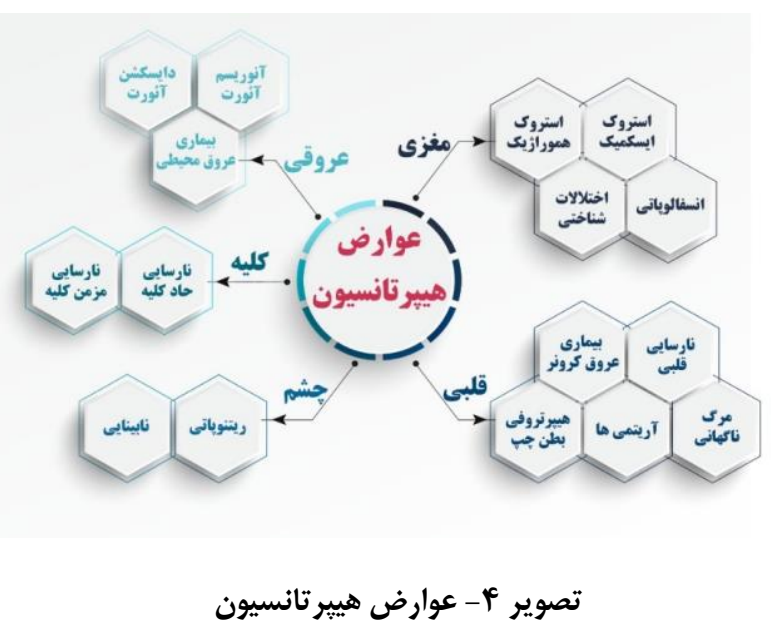

شرح حال

در شرح حال بيمار لازم است بلطور منظم و هدفمند در مورد سن شروع بيمارى، سوابق فاميلى و فردى، بيمارىهاى همراه، داروهاى مصرفى و غيره سؤالاتى يرسيد كه در جدول V آمده است.

معاينه فيزيكى هدف اصلى از معاينه فيزيكى بررسى شواهدى از علل ثانويه

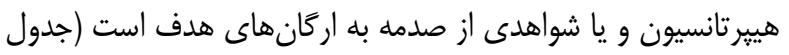

\section{روش هاى تشخيصى ياراكلينيك}

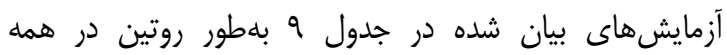
بيماران هييرتانسيو به منظور غربالحرى علل ثانويه هييرتانسيون انجام مى شود. ساير اقدامات تشخيصى بسته به شرايط بيمار انجام

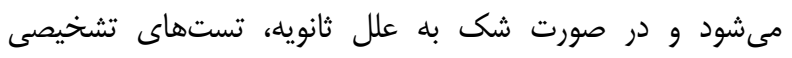
بيمارى مورد نظر بايد درخواست شود؛ به عنوان مثال در صورت GFR

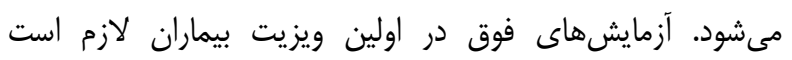

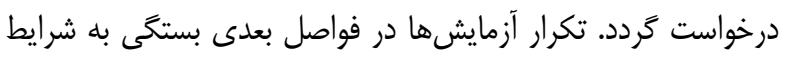
بيمار دارد و استاندارد مشخص و واضحى ندارد.

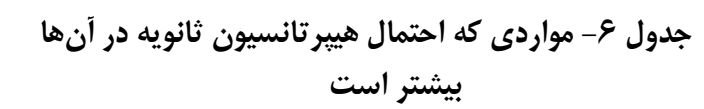

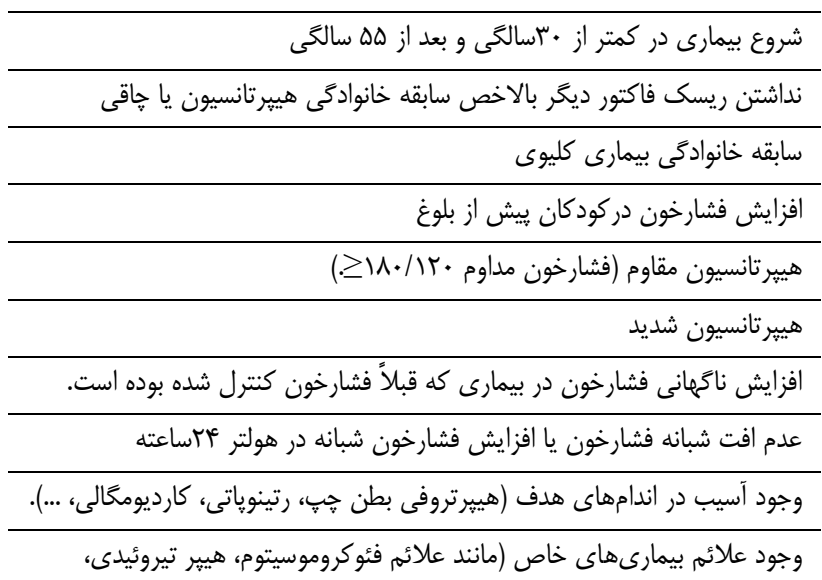

هييوتيروئيدى) سمع بروئى ابدومينال در معاينه شكم تفاوت نبض يا فشارخون در دست و پاها هييو كالمى بلدون توجيه مصرف داروهاى ايجاد كننده فشارخون

\section{عوارض هيبر تانسيون}

يكى از مهمترين علل كنترل و درمان فشارخون بالا صدماتى هيرتيون

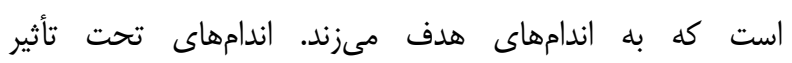
هييرتانسيون عبارتند از: سيستم قلبى عروقى (قلب، أئورت و هات

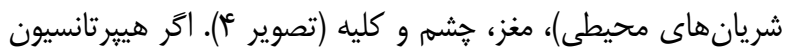

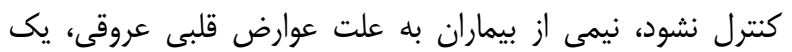

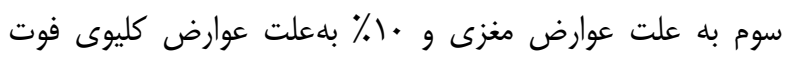
مىشوند؛ لذا لازم است براى جلوكيرى و ويا به تأخير انداختن

$$
\text { عوارض، فشارخون كنترل شود (19, 11). }
$$

\section{ارزيابى بيماران هيبر تانسيو}

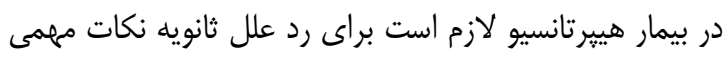

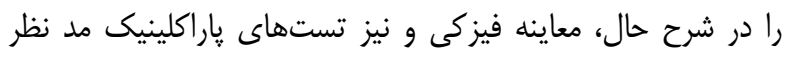


جدول V- نكات مهم در شرح حال بيماران هيبر تانسيو

\begin{tabular}{|c|c|c|}
\hline هرجه بيمارى بيشتر طول كشيده باشد، احتمال عوارض بيشتر است. & & طول مدت بيمارى \\
\hline شروع هييرتانسيون در سنين بايينتر احتمال هيير تانسيون ثانويه را افزايش مىدهد. & & سن شروع بيمارى \\
\hline احتمال هيير تانسيون اوليه بيشتر است. & سابقه فاميلى هيير تانسيون & \\
\hline احتمال هييرت تانسيون ثانويه بيشتر است. & فئوكروموسيتوم، ديابت كليوى، & سوابق فاميلى \\
\hline بشيمارى هارساى قلبى عروقى: بيمارى عروق كرونر، استروى، بيمارى عروق محيطى، بيمارى كاروتيد & بيمارى هاى ناشى از عوارض & \multirow{3}{*}{ سوابق بيمارى در فرد } \\
\hline ديابت، خاقى، ديس لييبدمى & عوامل خطر بيمارىهاى قلبى عروقى & \\
\hline 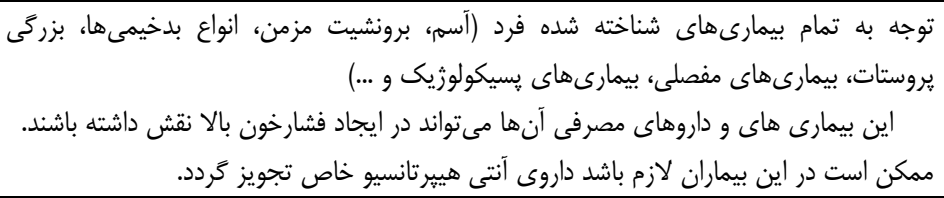 & 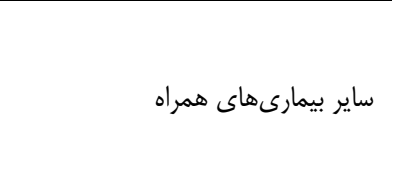 & \\
\hline ميزان مصرف نمك، سبزيجات، ميوهجات، فست فود و غيره & 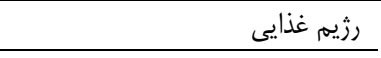 & \multirow{6}{*}{ 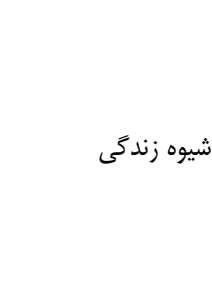 } \\
\hline ميزان فعاليت فيزيكى هوازى و شدت فعاليت مهم است. & ميزان فعاليت فيزيكى & \\
\hline مصرف سيكار، إيوم، الكل & 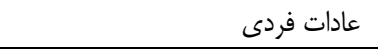 & \\
\hline خُر خُر شبانه، خواب آلودگى روزانه، اختلال خواب & 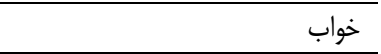 & \\
\hline شب بيدارى هاو استرسهاى شغلى & شغل & \\
\hline در همكارى بيمار در درمان مؤثر است. & ت تحصيلات & \\
\hline داروهاى مصرفى فعلى، قبلى، عوارض داروها و دوز مصرفى آنها & داروهاى آنتى هيير تانسيو & \multirow{2}{*}{ داروها } \\
\hline بعضى از داروهاى مصرفى مىتواند فشارخون را بالا ببرد (جدول ه) & 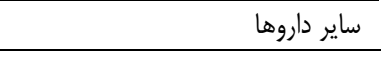 & \\
\hline سر درد، تِش قلب، سر كَيجه، وز وز كَوش، إيبستاكسى، ادم اندام & علائم بالينى هيير تانسيون & \multirow{3}{*}{ علائم بالينى } \\
\hline حملات سر درد، تِش قلب و تعريق، ضعف عضلانى، نوكجورى، هماجيورى & عالائم بالينى علل ثانويه & \\
\hline تنكى نفس، درد قفسه سينه، سر درد، اختلال ديد، تهوع و استفراغ & هيير تانسيون بيمارى هاى ناشى از عوارض & \\
\hline
\end{tabular}

جدول ^- نكات مهم در معاينه فيزيكى بيماران هيبر تانسيو

\begin{tabular}{|c|c|}
\hline توجه به ظاهر بيمار از نظر بيمارى هايى مانند بيمارى هاى تيروئيدى، آكرومكالى، كوشينگ & توجه به جهره \\
\hline بررسى سايز تيروئيد & معاينه تيروئيد \\
\hline سمع كناره تحتانى و קֶ استرنوم يعنى LLSB (سوفل نارسايى آئورت) & 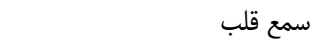 \\
\hline سمع كانون آئورت (سوفل آئورت دولتى) & \\
\hline سمع سويراكلاويكل جِ (كوراكتاسيون أئورت) & \\
\hline \multicolumn{2}{|l|}{ سمع فضاهاى بين دنده اى ع تا م در يشت قفسه سينه (كوراكتاسيون آئورت) } \\
\hline توجه به ويز و رال و كاهش صداهاى ريوى & 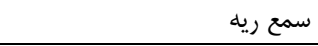 \\
\hline بررسى از نظر استرياى شكمى (كوشينگ) & معاينه شكم \\
\hline \multirow{2}{*}{\multicolumn{2}{|c|}{ معاينه لوز دور ناف از نظر بروئى ابدومينال (تنكى شريان كليه) }} \\
\hline & \\
\hline \multicolumn{2}{|l|}{ بررسى ادم در اندامها از نظر نارسايى قلبى، نارسايى كليوى، هييوتيروئيدى } \\
\hline 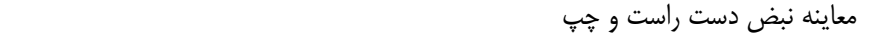 & 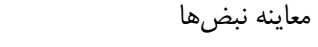 \\
\hline \multicolumn{2}{|l|}{ مقايسه همزمان نبض راديال با فمورال (كوراكتاسيون أئورت) } \\
\hline بررسى رتينوياتى هيير تانسيو & معاينه ته جشم \\
\hline بررسى اضافه وزن، حاقى يا קاقى شكمى با اصلاح آنها فشارخون هم پايينتر مى آيد. & اندازه گيرى قد، وزن ، دور شكم \\
\hline
\end{tabular}




\begin{tabular}{|c|c|}
\hline كنترل دقيقتر فشارخون در صورت همزمانى ديابت & 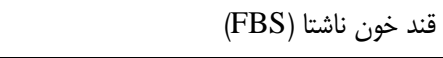 \\
\hline اجتناب از تجويز داروهاى مختل كننده ليييد & يروفايل ليييد (Chol, TG, HDL, LDL) \\
\hline 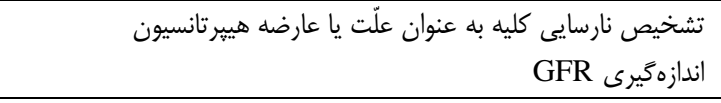 & اوره، كراتينين (Urea, Cr) \\
\hline هماجورى، يروتئين اورى، كيست ادرارى & 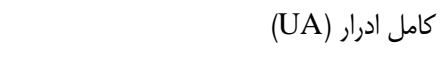 \\
\hline همزمانى يلى ديتمى ورا با هيير تانسيون & شمارش كامل خون (CBC) - (CBC) \\
\hline هيير آلدوسترونيسم اوليه & سديه، يتاسيه (Na , ) \\
\hline هيير كلسمى و هيبرياراتيروئيديسم & كلسيم (Ca) - (Ca) \\
\hline هييو تيروئيدى، هيير تيروئيدى & هورمون تيروئيد (TSH) \\
\hline 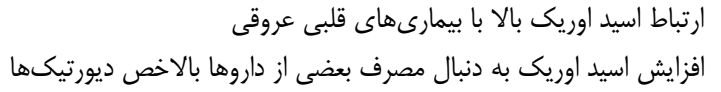 & اسيد اوريك (Uric acid) \\
\hline به عنوان يك نوار قلب پايه، بررسى وجود LF ، & نوار قلب (ECG) \\
\hline
\end{tabular}

د) در هيج گروهى بالاخص گروه ب و ج، فشارخون دياستوليك إنى نبايد به كمتر از • V ميلى متر جيوه برسد.

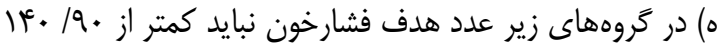

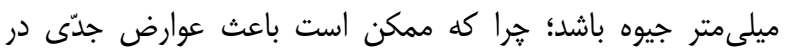

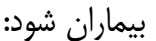
- - - - بيمارانى كه فشارخون متغير و علايم هييوتانسيون ارتوستاتيك دارند. بيمارانى كه دجار عوارض داروها شدهاند.

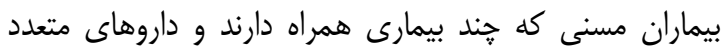
مصرف مى كنند. بيماران مسنى كه در آسايشخاهها و يا تنها در منزل زندگى مى ميند كنند.

نكته: تغييرات فصلى فشارخون: فشارخون با تغييرات

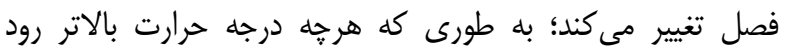
فشارخون بايينتر مى آيد، يعنى در فصل تابستان فشارخون ممكن

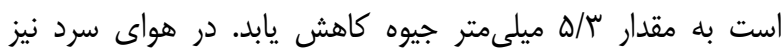

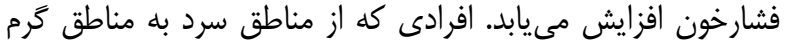

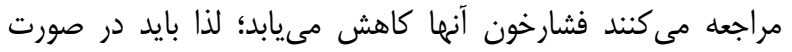

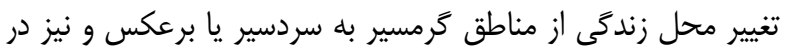

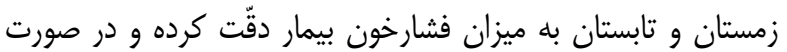

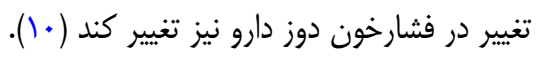

فالوآي و غربالگَرى

بر اساس تمام كايدلاينها در همه افراد بالاى 1 السال سال

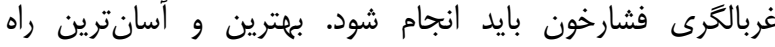

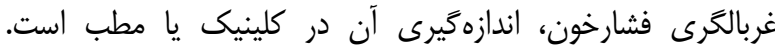

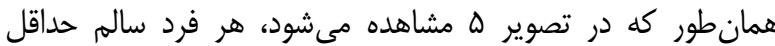

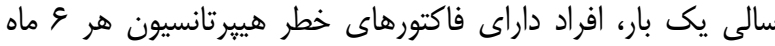

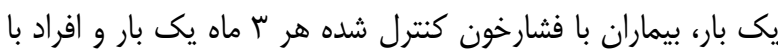

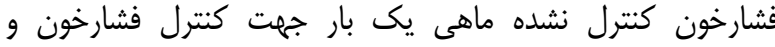
ويزيت مراجعه نمايند.

\section{عدد هدف در كنترل فشارخون (Target BP)}

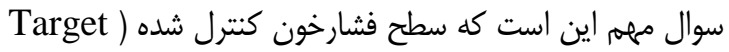

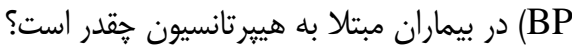

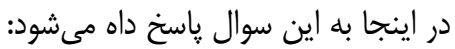

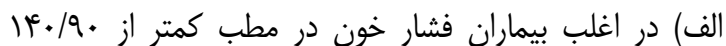
ميلىمتر جيوه و در منزل كمتر از هـ/هسا ميلىمتر جيوه به عنوان دران فشارخون هدف در نظر ترفته ميى شود.

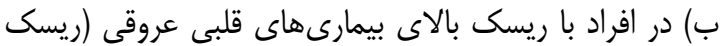

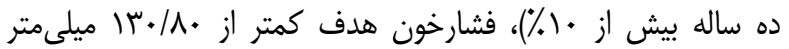
جيوه در نظر گرفته مى شيود.

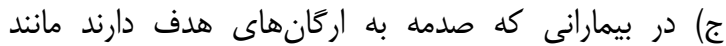

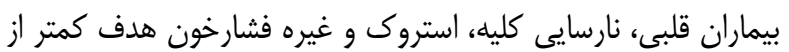

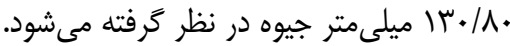




\section{درمان غيردارويى}

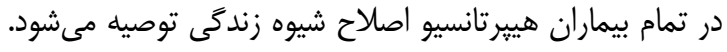

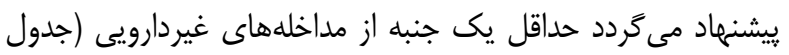

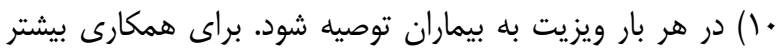

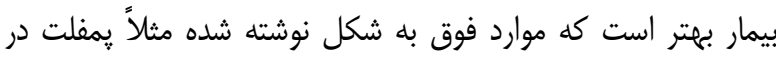
اختيار بيمار يا همراهان قرار كيرد.
درمان فشارخون بالا به دو روش مداخلات غير دارويى و درمان

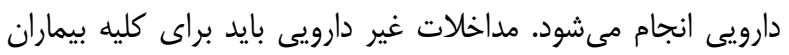

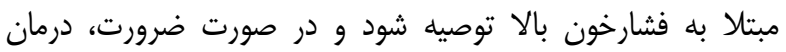
دارويى نيز شروع گردد.

\section{جدول + ( - بهترين مداخلات غيردارويى به منظور بيشَّيرى و كنترل هيبر تانسيون}

\begin{tabular}{|c|c|c|c|c|}
\hline \multicolumn{2}{|c|}{ 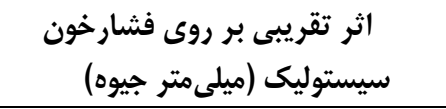 } & \multirow[t]{3}{*}{ ميزان } & \multirow[t]{3}{*}{ مداخله غيردارويى } & \\
\hline & ل درافراد & & & \\
\hline فشارخون طبيعى & هيير تانسيو & & & \\
\hline 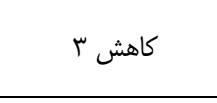 & 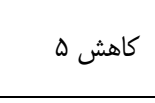 & 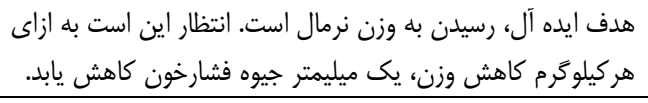 & وزن/ إقى بدن & 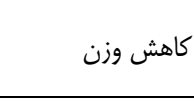 \\
\hline كاهش ץ & كاهش & 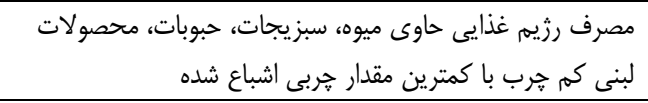 & $\begin{array}{r}\text { الكوى تغذيهاى } \\
\text { 'DASH }\end{array}$ & تغذيه سالم \\
\hline كاهش r-r & كاهش ع-ه & 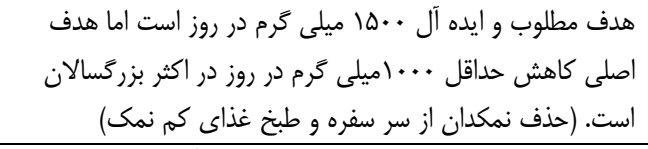 & سديم رزيم غذايى & كاهش جذب سديم \\
\hline كاهش & كاهش & 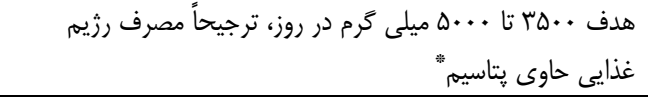 & 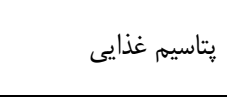 & 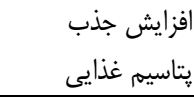 \\
\hline 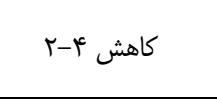 & 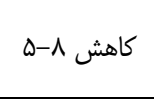 & 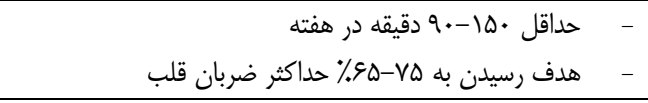 & ورزش ائروبيك & \\
\hline كاهش r & كاهش F & 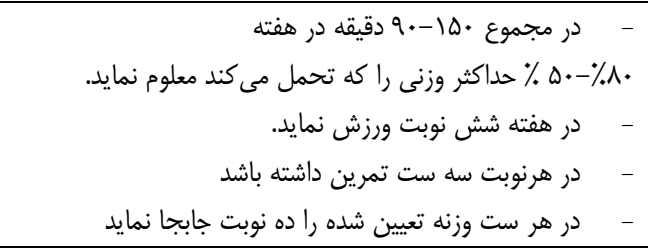 & $\begin{array}{r}\text { ورزش مقاومتى يويا } \\
\text { وزند جابجا كردن }\end{array}$ & فعاليت فيزيكى \\
\hline كاهش F & كاهشه & - & 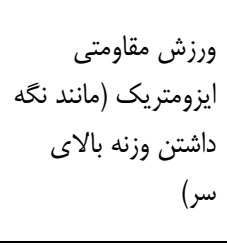 & \\
\hline 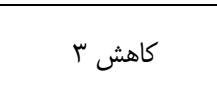 & 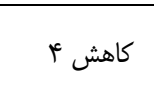 & در افرادى كه الكل مصرف مى كنند كاهش مصرف آن".". & مصرف الكل & مداخله در مصرف \\
\hline
\end{tabular}

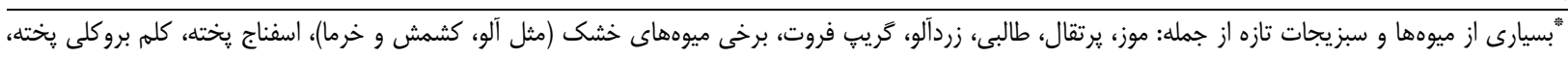

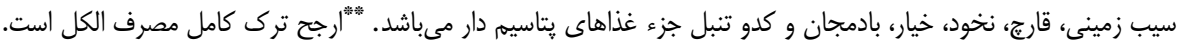

\footnotetext{
${ }^{1}$ Dietary Approaches to Stop Hypertension
} 
سيس در صورت عدم كنترل فشارخون درمان دارويى شروع كرد.

\section{انتخاب نوع دارو}

تمام داروهاى فشارخون كه در درمان فشار خون بهكار مىروند،

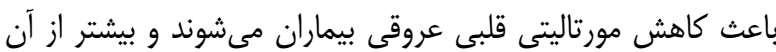

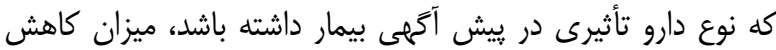

فشارخون، تحمل بيمار و عوارض داروها درانتخاب دارو مؤثر است. ينج دسته دارويى كه اغلب براى كنترل فشارخون بالا توصيه

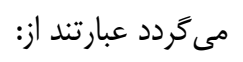

- بلوى كنندهای كانال كلسيم (CCBs)

ACE ) مهار كنندهاى سيستم رنين آنزيوتانسين -

(inhibitors

- بلوى كنندهاى رسيتور آنزيوتانسين (ARBs)

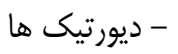

- بتابلوكرها (به طور معمول خط اول درمان محسوب نمىشود

اما در شرايط خاص كه در جدول rا آمده است به عنوان داروى خط

$$
\text { اول استفاده مىشود.) - (اسل }
$$

در بيمارانى كه دارو شروع مىشود مواردى كه در جدول Iا به

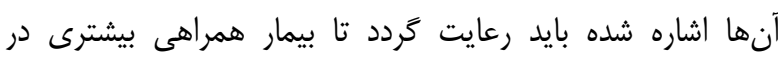
مصرف دارو و كنترل فشارخون داشته باشد.

در پيايان سه نمونه از مراحل شروع درمان دارويى بر اساس داس داسل

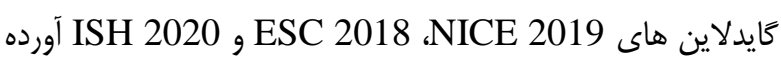

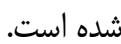

درمان دارويى

اغلب بيماران براى كنترل ايدهآل فشارخون بالا علاوه بر روشهاى اصلاح سبك زندگى به دارو درمانى نيز نياز دارند. درمان

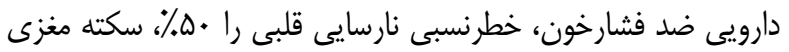

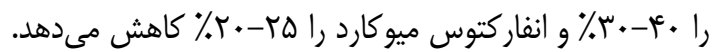

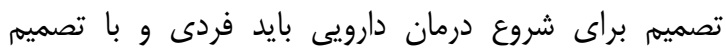
مشترى بيمار و زيزشى باشد و ييشنهاد مى"ردد داروهاى ضدفشارخون در موارد زير مورد استفاده قرار گيرد (تصوير ه).

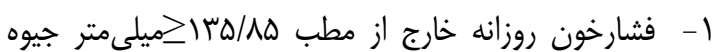

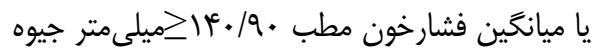

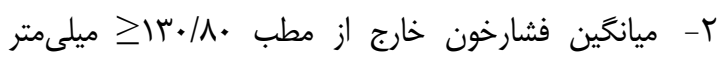

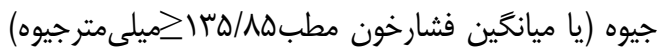

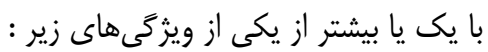

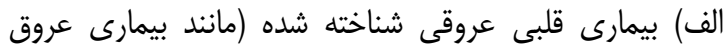
كرونر، بيمارى ايسكميك قلبى پايدار، نارسايى قلبى، بيمارى كاروتيد، استروى قبلى، يا بيمارى عروق محيطى). ب) ديابت نوعr ج) سن هاء سال يا بالاتر د) نارسايى مزمن كليه

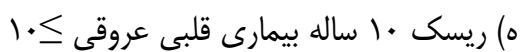
نكته: در درمان دارويى بيمارانى كه در مرحله يك فشارخون

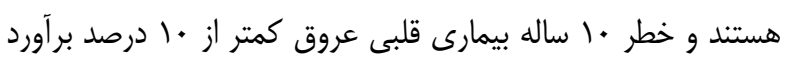

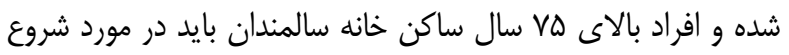

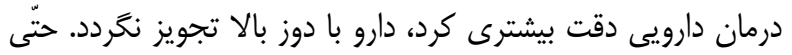

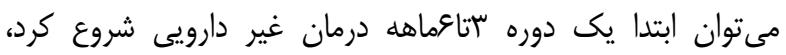




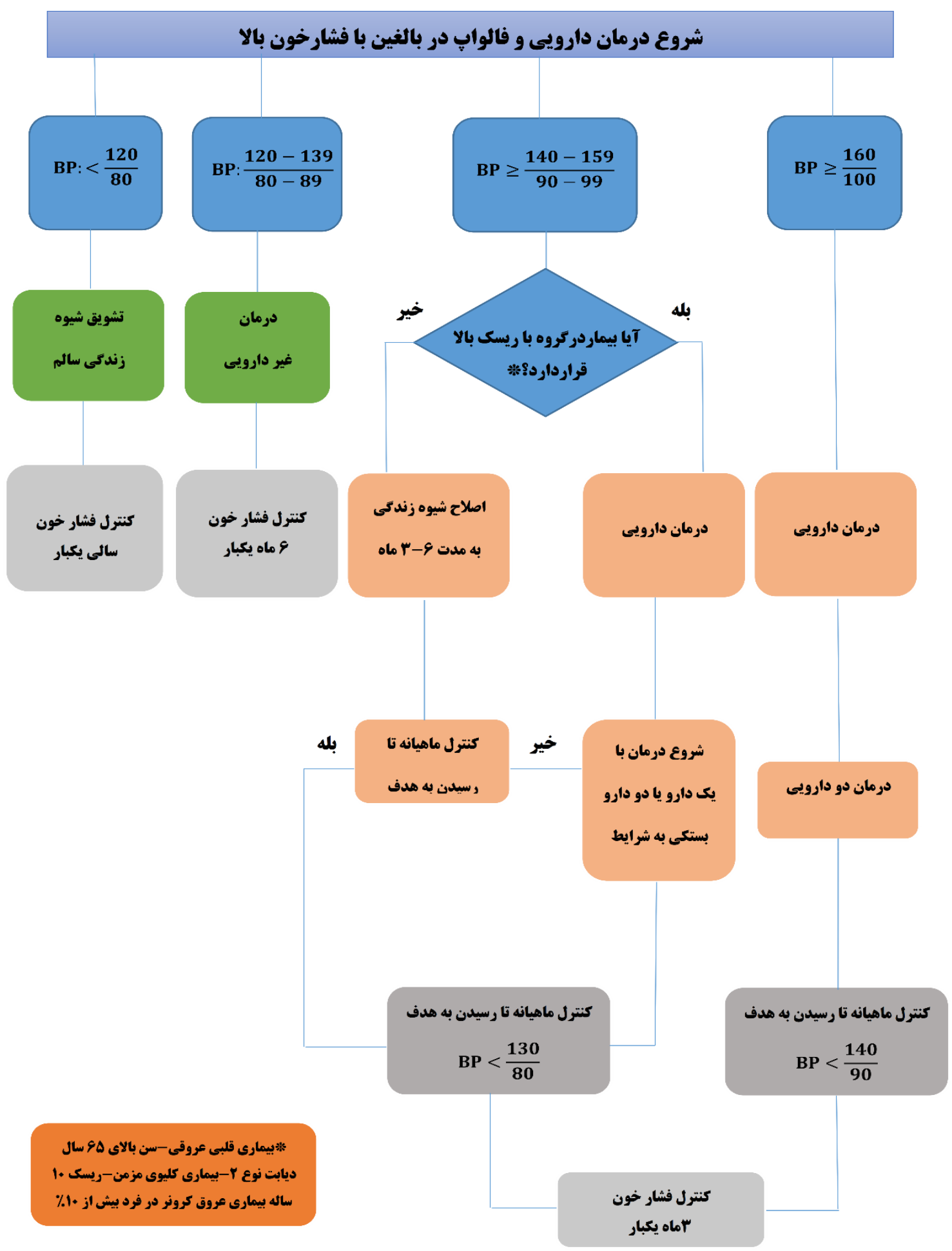

تصوير ه- الكَوريتم شروع درمان دارويى و فالواب در بالغين با فشارخون بالا 


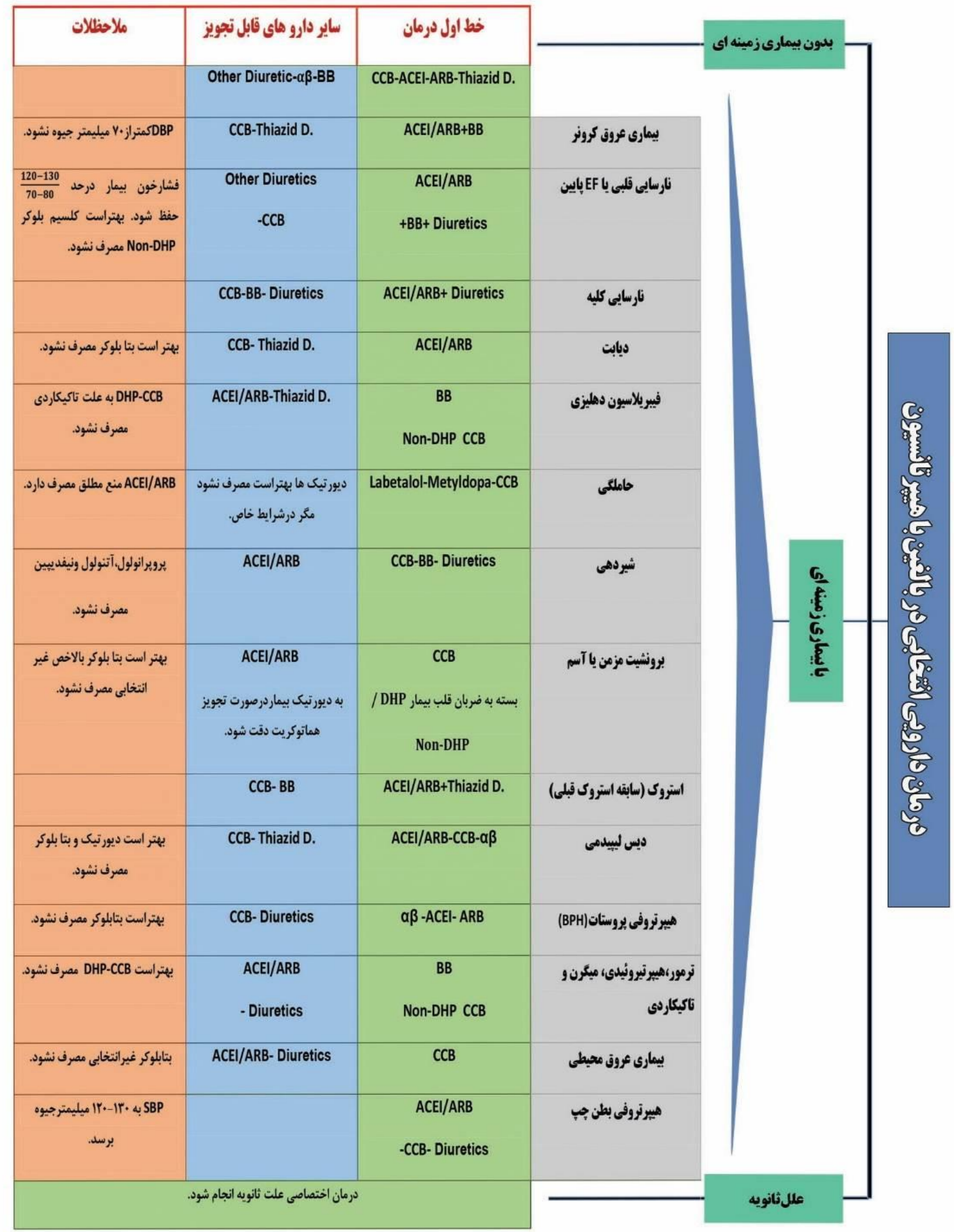

تصوير צ- درمان دارويى انتخابى در بالغين با هيبر تانسيون 
جدول || - استراتزى هاى كلى دارو درمانى در بيماران هيبر تانسيو

اكر بيمار، بيمارى همراه خاصى ندارد با يكى از f دسته داروى زير مىتوان درمان را شروع كرد:

$$
\text { مهار كنندهاى آنزيم (ACEI) }
$$

بلوى كندههاى رسيتور آنثيوتانسين (ARB)

بلوى كنندهاى كانال كلسيم (CCB) بهخصوص كَروه دى هيدروييريدين (DHP) مثل آملودييين و نيفدييين

ديورتيكهاى تيازيدى

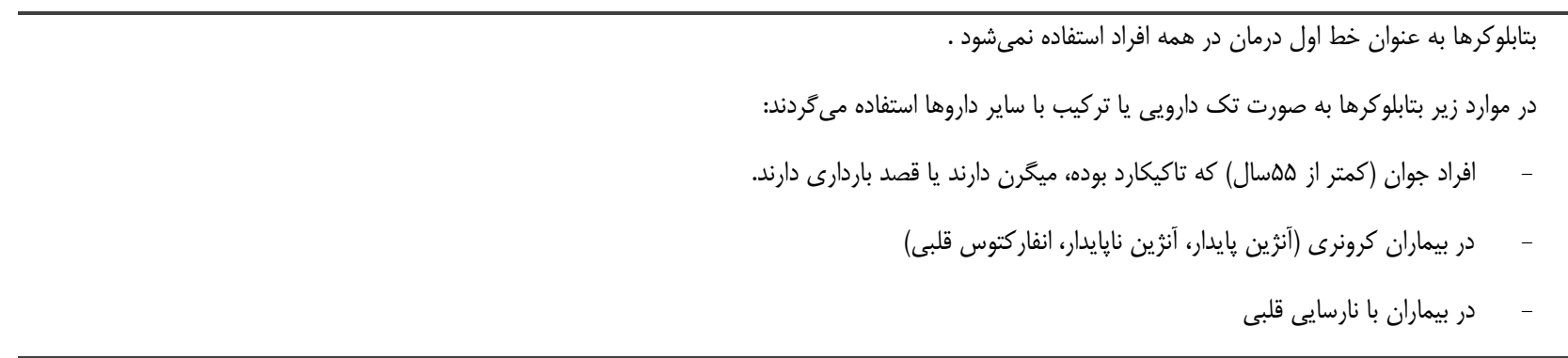

اكر بيمارى همراه خاصى وجود دارد بر اساس نكاتى كه در تصوير 9 أورده شده دارو انتخاب مى كردد.

بهتر است يك دارو و يك بار در روز تجويز كردد (بهتر است به صورت يك قرص تركيبى') تا مصرف دارو راحتتر باشد.

در صورت نياز به درمان دو دارويى، داروهاى تركيبى با حداقل دوز استفاده مىشوند (تصوير V):

ARB + thiazide diuretic $\quad$ ي ACEI + thiazide diuretic $\quad ا \quad$ ARB + CCB $\quad ا \quad$ ACEI+ CCB

-درمان تركيبى در افراد مسن (بيش از •م سال)، در افراد با فشارخون سيستولى كمتر از •إ ميلىمترجيوه توصيه نمىشود.

- درمان تركيبى ACEI بال ARB منع مطلق دارد و توصيه نمىشود.

اكر علىرغم مصرف دو دارو فشارخون كتترل نشد، از تركيب سه دارويى استفاده مىشود:

$\mathrm{ARB}+\mathrm{CCB}+$ thiazide diuretic $\quad$ ي $\mathrm{ACEI}+\mathrm{CCB}+$ thiazide diuretic

اكر علىرغم درمان بّ دارويى فوق همجنان فشار بالا بود، بايد به هييرتانسيون مقاوم شك كرده و علاوه بر بررسى علل آن، دوز و تعداد داروها افزايش يابد:

- اضافه كردن اسييرونولاكتون با دوز كم يا ساير ديورتيكها بر اساس يتاسيم و كراتينين بيمار

- - اضافه كردن بتابلوكر يا آلفا بلوكر

بيمار به سطوح بالاتر يا كلينيك تخصى فشارخون ارجاع شود.

در مورد هزينه دارو دقت شود كه از داروهاى كران قيمت بالاخص براى افراد با سطح اجتماعى اقتصادى بإيين استفاده نشود يا بيمار بهطور كامل از نظر مصرف دارو

توجيه شود.

در انتخاب نوع دارو در زنان شيرده و زنانى كه قصد باردارى دارند بايد دقّت شود.

${ }^{1}$ SPC (single pill combinantion) 


\section{Antihypertensive Drug Treatment}

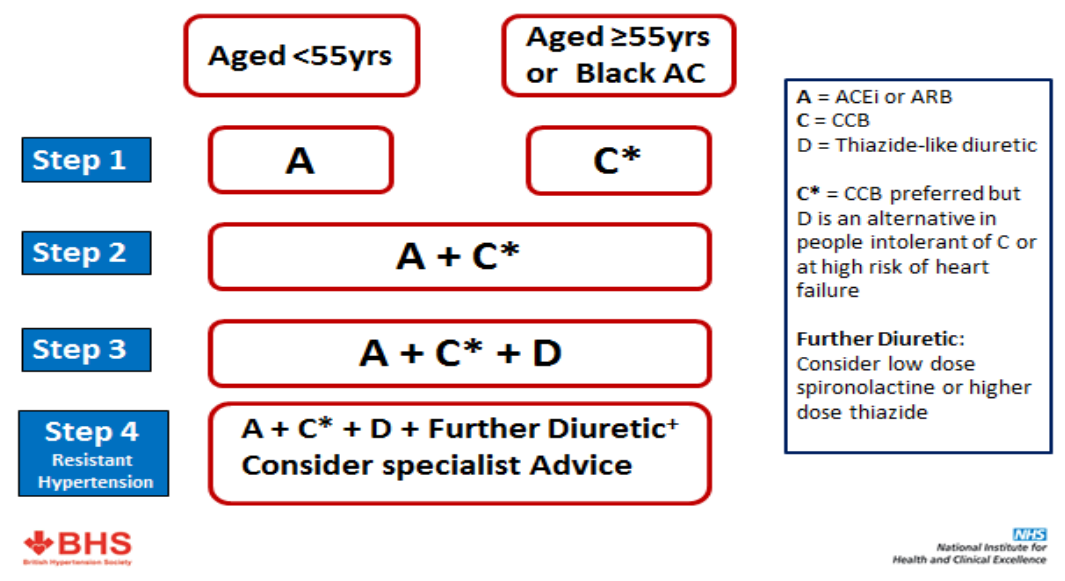

الف) كَايدلاين درمان دارويى آنتى هيبر تانسيو NICE 2019 (r. NI

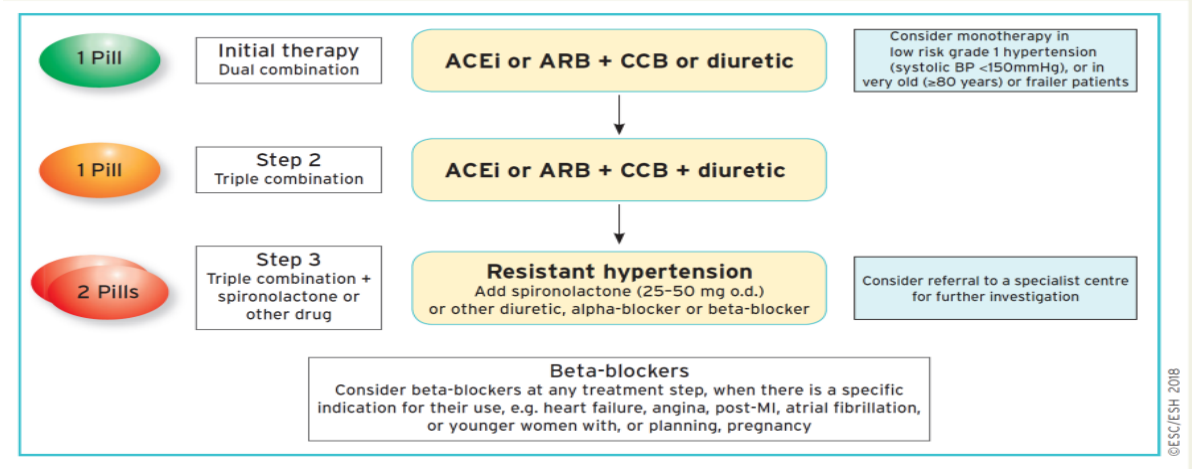

ب) ESC 2018 (ᄉ) Eايدلاين درمان دارويى آنتى هيير تانسيو

\section{ESSENTIAL}

- Use whatever drugs are

available with as many

of the ideal charac:

teristics (see Pa6/e 9)

as possible.

- Use free combinations if

SPCs are not available

or unaffordable

- Use thiazide diuretics

if thiazide-like diuretics

are not available

- Use alternative to DHP

CCBs if these are not

available or not tolerated

available or not tolerate

ditiazem or verapamit.

\section{Drug choice}

\section{\& Sequencing}

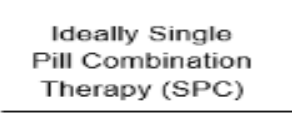

Pill Combination

Therapy (SPC)

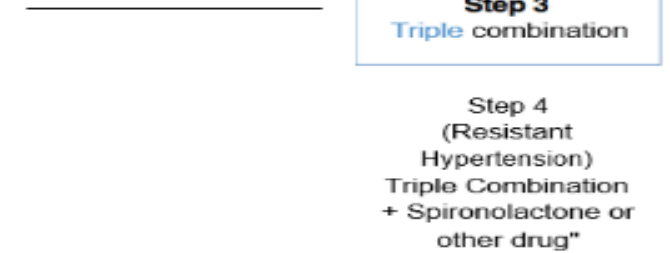

ج) تايدلاين درمان دارويى آنتى هيبر تانسيو 2020 ISH (.) other drug"

O P T I M A L

\begin{tabular}{|c|}
\hline $\begin{array}{c}\text { Mup } \mathbf{1} \\
\text { Dual low-dose\# } \\
\text { combination }\end{array}$ \\
\hline $\begin{array}{c}\text { Step 2 } \\
\text { Dual full-dose } \\
\text { combination }\end{array}$ \\
\hline Step 3 \\
\hline Triple combination \\
\hline Step 4 \\
(Resistant \\
Hypertension) \\
Triple Combination \\
+ Spironolactone or \\
other drug"
\end{tabular}

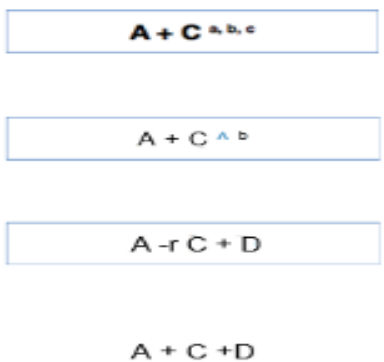

Add spironolactone (1Z.5-50 mg o.d. $)^{\mathrm{d}}$ 
جدول ז I - انواع داروهاى كاهنده فشارخون و دوز آنها

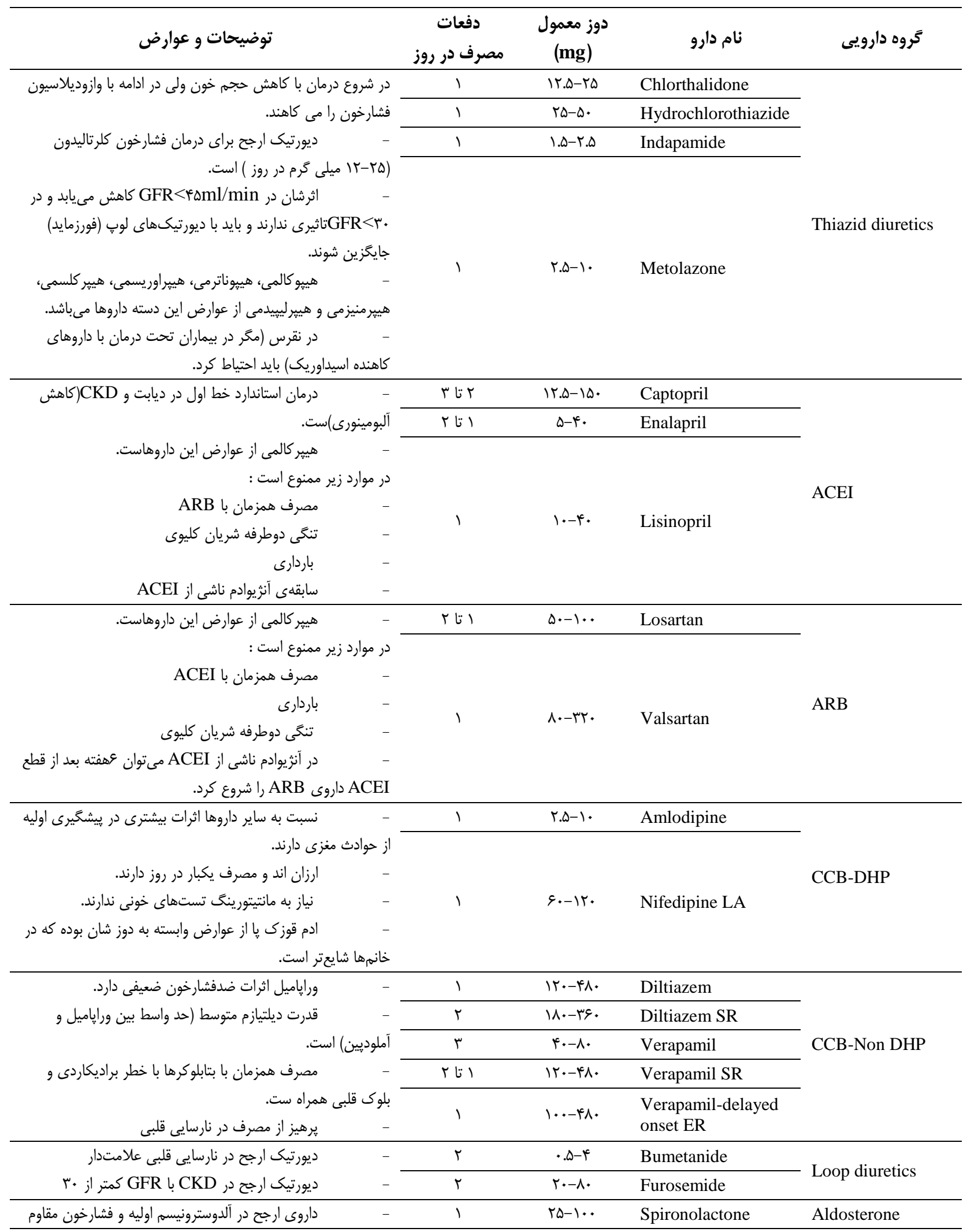




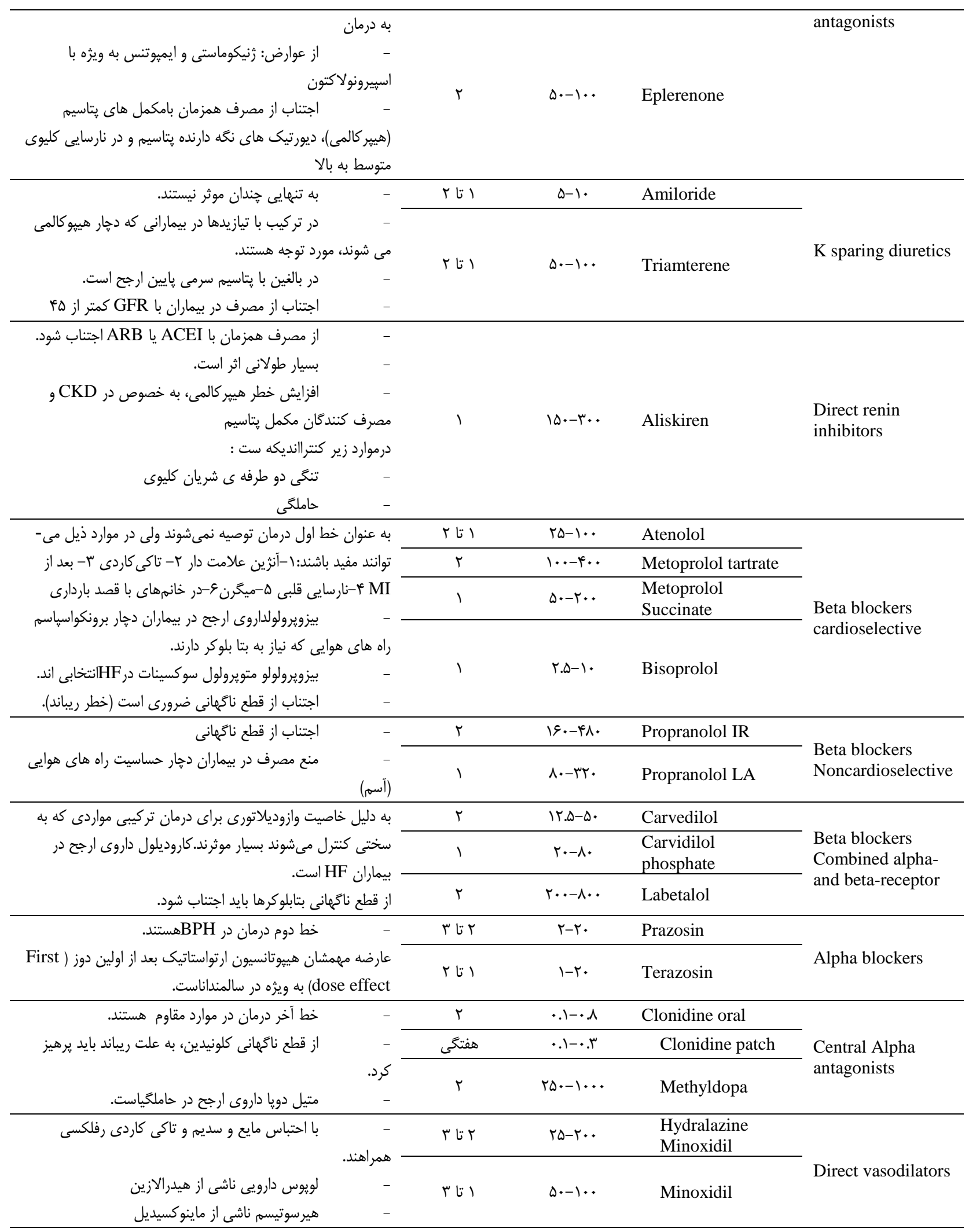


هفته بعد از قطع دارو بهبود مى يابد.

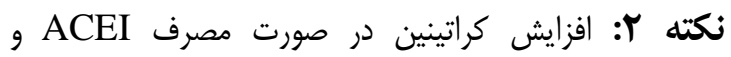
ياARB در افرادى كه تنكى دو طرفه شريان كليوى، كليه

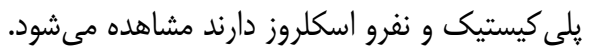

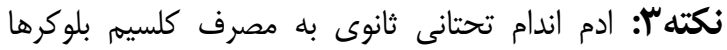

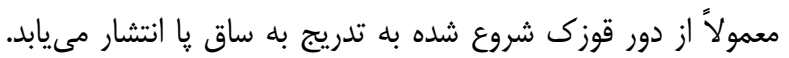

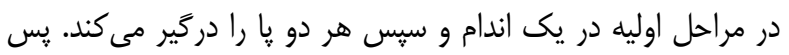

$$
\text { از قطع دارو، ادم در مدت كوتاهى بركشت مى كند. }
$$

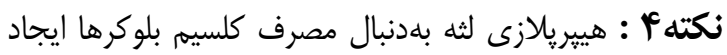

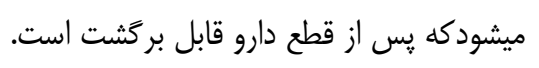

\section{انديكاسيون هاى كاهش دوز داروهاى فشارخون و كاهى قطع آنها}

معمولاً بيماران هييرتانسيولازم است تا بايان عمر داروى فشارخون را مصرف كنند. در هاء از بيماران ممكن است بتوان دارو را با رعايت احتياطهاى لازم قطع كرد. در بيمارانى كه درمانهاى دارويى و غيردارويى را به خوبى رعايت كنند به دليل كاهش

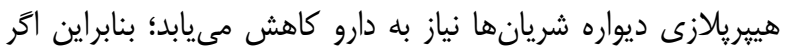

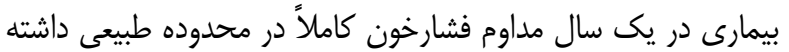
باشد، مى توان دارو را كم و حتّى با احتياط قطع كرد، بهخصوص درد مرد

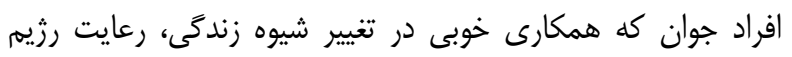
غذايى و كنترل وزن دارند. در صورت كم كردن يا قطع دارو لازم است بيمار به طور منظم فشارخون خود را كنترل نمايد.

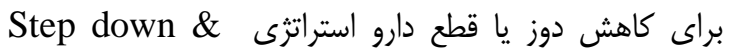
"close follow up" ماه r-1 بار جهت كنترل فشارخون بيمار مراجعه نمايد، اگر در اين سه ماه فشارخون در حد ثابت و قابل قبول بود دوز دارو كم شود،

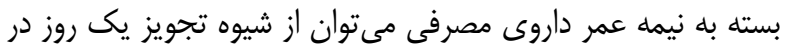

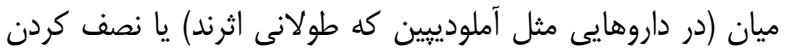
دوز دارو استفاده كرد.
نقش و اهميت داروهاى Fixed Dose Combination در درمان فشارخون بالا نكته مهم در تمام كايدلاينهاى اشاره شده در اين مقاله،

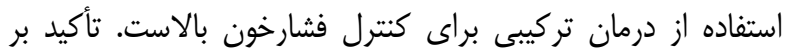
استفاده از r كلاس دارويى مختلف از داروهاى خط اول درمان است.

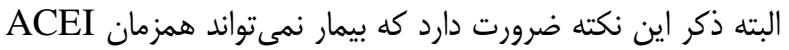
و بحيرد. ARB

Fixed Dose مطالعات مختلف نشان مادند نسبت بله مونوترايى باعث كاهش بيشتر وسريعتر

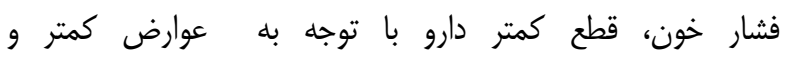

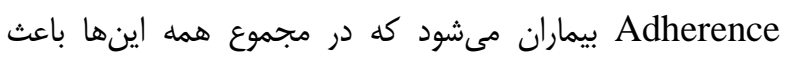
بهبود Outcome بيماران فشارخون شده است. نهايتاً به واسطه

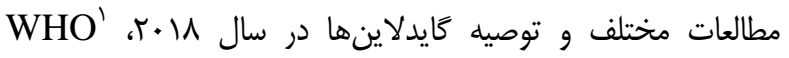

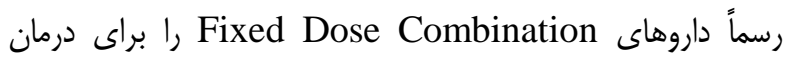
فشارخون به عنوان داروهايى مؤثر، سالم و ساده به جهت در دسترس بودن و قيمت مناسب وارد ليست داورهاى ضرورى خود كرد، يعنى اينها داروهاى مهمى براى بهبود سلامت جامعه هستند و در سياست كذارى كشورهاى مختلف بايد به صورت ساده و همه كير در

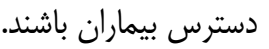
از جمله داروهاى Fixed Dose Combination موجود در بئد ايران تركيبات والسارتان+آملودييين (Valsomix , Synomix)،

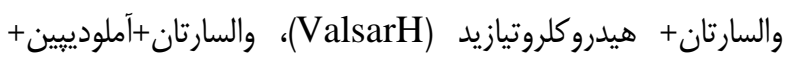
هيدروكلروتيازيد (Valsomix HCT)، لوزارتان + هيدروكلروتيازيد (Losar H , Losamix)

\section{نكات عوارض داروها}

نكته (: از عوارض شايع ACEI سرفه مىباشد كه ابتدا به صورت خشكى گلو سيس سرفهاى كاه گَاهى و در مراحل ييشرفته سرفه هاى قطارى، مكرر و خشى ايجاد مى گردد. در صورت بروز

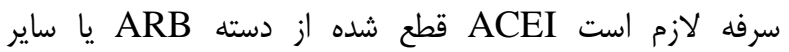
كروههاى جايكزين گرددد. اكر سرفه عارضه ACEI باشد، يك تأ

\footnotetext{
${ }^{1}$ World Health Oraganization
} 
بعد از رد هيير تانسيون مقاوم به درمان كاذب، موارد زير مد نظر قرار گيرد: - ميعد

1- بررسى از نظر علل ثانويه هييرتانسيون شامل هيير آلدوسترونيسه اوليه، نارسايى مزمن كليه، تنگى شريان كليه، فئو كروموسيتوم وآينه انسدادى خواب.

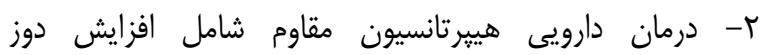
ديورتيك به حداكثر، اضافه كردن يك آنتى آلدوسترون (اسبرينولاكتون و در صورت عدم تحمل ايلرنون)، استفاده از ديورتيكهاى لوب به جاى تيازيد (در بيماران با GFR كمتر

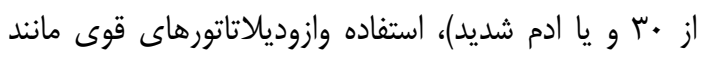

$$
\text { مينوكسيديل. }
$$

r- ارجاع به متخصص يا به سطح بالاتر يا كلينيك هييرتانسيون

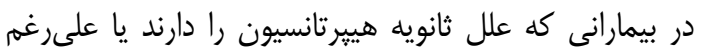
عماه درمان همجنان فشارخون به حد كتترل نرسيده است.

\section{هيير تانسيون بحر انى (كريز هيير تاسيون، HTN Crisis )}

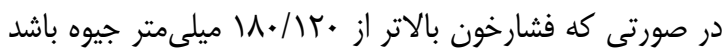

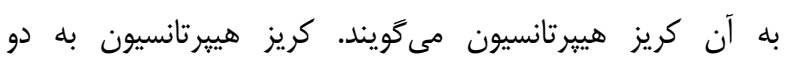
كروه HTN emergency

الف) HTN emergency: در صورتى كه فشارخون بالا همراه با صدمه به اركان هاى هدف باشد (انسفالوياتى هيبرتانسيو،

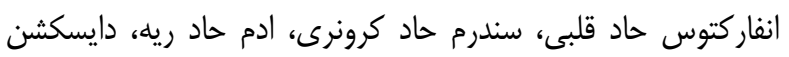

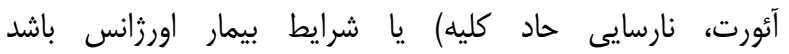
(يرهاكلاميسى، اكلامبسى، قبل از عمل جراحى اورزانس، بعد از عمل

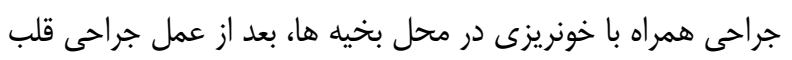

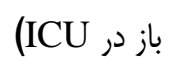

لازم است اين بيماران در بخش مراقبتهاى ويزه بسترى

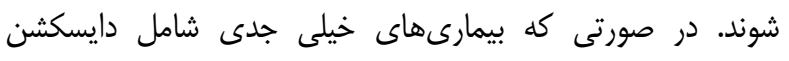

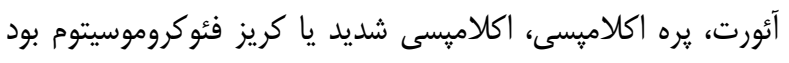

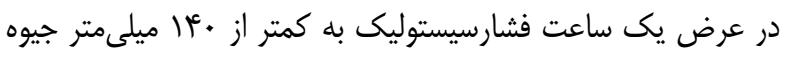

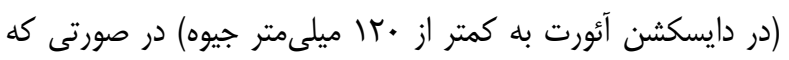

\section{هيبر تانسيون مقاوم به درمان (Resistance HTN)} زمانى كه فشارخون اندازهميرى شده علىرغم درمان با سه يه يا بيشتر داروهاى آنتى هييرتانسيو شامل يك ديورتيك و با حداكثر دوز

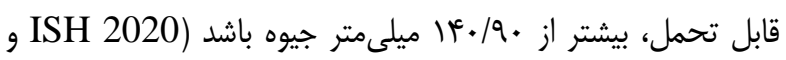

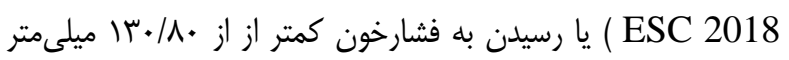

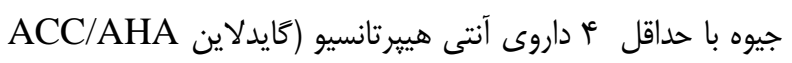

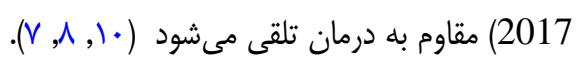

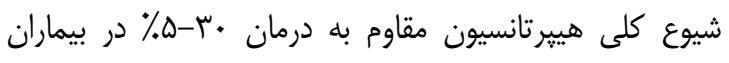

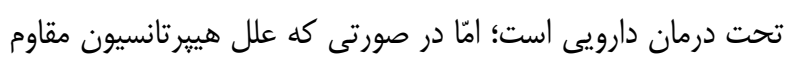

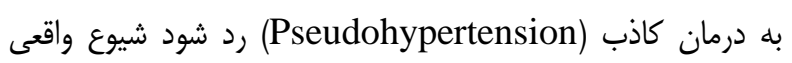
آن كمتر از • (\% است. هيير تانسيون مقاوم به درمان با افزايش خطر بيمارى هاى قلبى عروقى، نارسايى كليه و مرك و مير همراه است.

\section{رويكرد تشخيصى و درمانى در هيبرتانسيون مقاوم به}

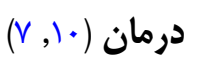

ابتدا بايد علل كاذب هييبرتانسيون مقاوم رد شود. اين موارد

$$
\text { عبارتند از: }
$$

1- تكنيك ضعيف اندازهگيرى فشارخون در مطب: مثلاً استفاده

از كاف كوجى نسبت به دور بازو، عدم استراحت قبل از اندازهيرى، رعايت نكردن نكات استاندارد كَرفتن فشار خون.

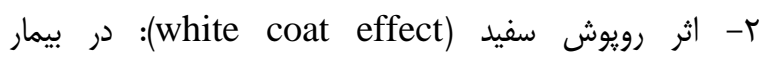
فشارخونى تحت درمان دارويى اخر فشارخون اندازهيرى شده در مطب بالاست اما در هولتر بأ ساعته يا كنترل فشارخون در منزل نرمال است بايد به اين پيديده فكر كرد، ناشايع نيست. r- بررسى و رفع فاكتورهاى مرتبط با شيوه زندكى كه مانع

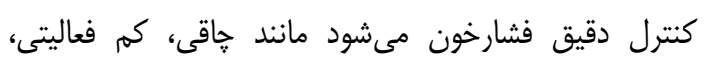
مصرف بيش از حد الكل، رزيم غذاى شور و كم فيبر.

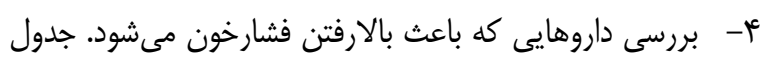
ז محركها، قرص ضدباردارى (OCP) و شيرين بيان: اين داروها بايد قطع شود يا ميزان آن به حداقل برسد. 
گردد و توضيحات كافى به بيمار و همراهيان در مورد مصرف منظم دارو و رعايت رزيهم غذايى و غيره داده شود. همجنين مراجعه هر جه سريعتر به يزشك معالج به بيمار توصيه شود. در غير اين صورت اين

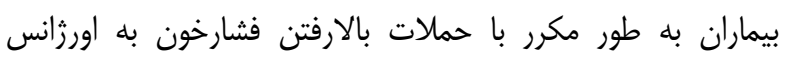
مراجعه خواهند كرد. يروگنوز و فالواب و بقاى اين بيماران در طى جند دهه كذشته بهبود يافته اما باز هم اين گروه در ريسك بالايى قرار دارند و بايد از نظر علل ثانويه بررسى شوند و بعد ازاينكه فشارخون به حد ثابتى رسيد و سطح درمان داروى خوراكى به حد مورد نظر رسيد بيمار از بيمارستان ترخيص شده ييشنهاد اين است كه حداقل ماهى يك بار بيمار ويزيت شود تا به حد فشارخون مورد نظر برسد.
موارد فوق وجود نداشت، فشارخون در ساعت اول حداكثر هr\%

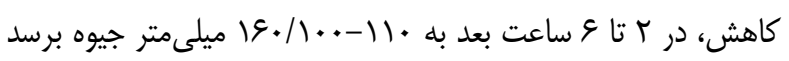

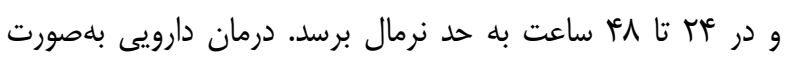
تزريقى و طبق جدول سا بايد تجويز زردد. ب):HTN urgency: بالابودن فشارخون در حد بحرانى امّا صدمه به اركًانهاى هدف وجود ندارد يا شرايط بيمار خيلى اورزانسى نيست (در بيمار بسترى قبل از عمل جراحى الكتيو، بالارفتن فشارخون بعد از عمل جراحى بدون خونريزى از محل بخيهها). بيمار تحت نظرگرفته شده اغلب با تجويز يك دوز از داروى خوراكى

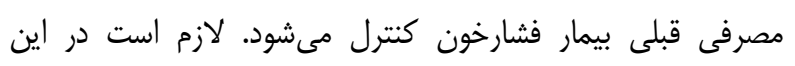

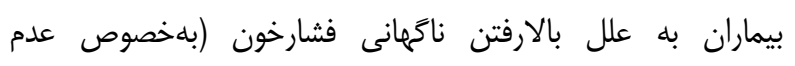
كميليانس بيمار) دقت شود و داروهاى بيمار به طور دقيق اصلاح

جدول سا - اورزانس هاى فشارخون و درمانها

\begin{tabular}{|c|c|c|c|c|}
\hline داروى خط دوم & داروى خط اول & فشارخون هدف & مدتار زمان رسيدن به هدف & ت تظاهر بالينى \\
\hline نيترويروسايد & لابتالول & در طى خند ساعت & 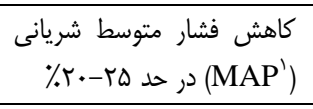 & نارسايى حاد كليه \\
\hline نيترويروسايد & لابتارلو & 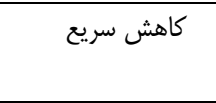 & 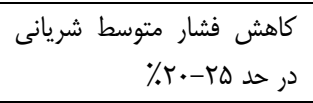 & آنسفالوياتى هيير تانسسيو \\
\hline نيترويروسايد & لابتالول & يك ساعت & 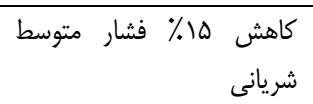 & استروك حاد ايسكميك و \\
\hline نيترويروسايد & لابتارول & يك ساعت & 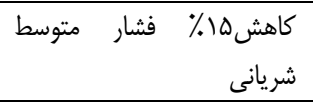 & 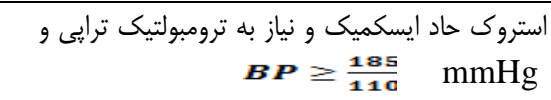 \\
\hline 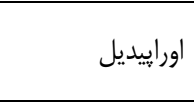 & لابتارول & كاهش سريع & $\mu^{\mu}<\mathrm{SBP}<\|$ & SBP>180 mmHg استروى حاد همورازيك و \\
\hline - & 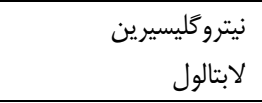 & كاهش سريع & $\mathrm{SBP}<1)^{4}$ & سندرم حاد كرونرى \\
\hline - & 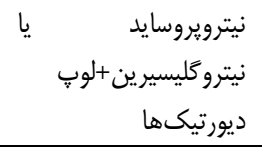 & كاهش سريع & $\mathrm{SBP}<14$. & ادم حاد ريه \\
\hline \multirow[t]{2}{*}{ تلابتالول } & يا يا نيتروكَليسيرل و نيترويروسايد & كاهش سريع & $\begin{array}{r}\text { SBP } \\
H R<9 .\end{array}$ & دايسكشن أئورت \\
\hline & 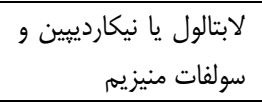 & كاهش سريع & $\mathrm{DBP}<1 \cdot \Delta, \mathrm{SBP}<19$. & اكلامِّى يا يره اكلامِيسى شديد يا HELLP \\
\hline
\end{tabular}

\footnotetext{
${ }^{1}$ Mean Areterial Pressure
} 
يروتيئناورى قابل توجه (يعنى بيش از ..ب ميلى

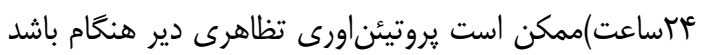

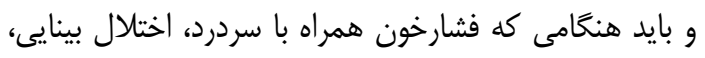

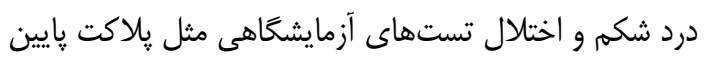
يا اختالال تستهاى كبدى است مورد شك قرار كيرد. f- اكلاميسى: هيبرتانسيون به همراه تشنج، سردرد شديد،

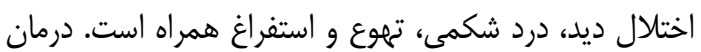
فشارخون اورزانس بوده و بايد ختم باردارى هم داد.

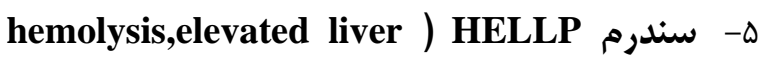
enzymes,low platelets

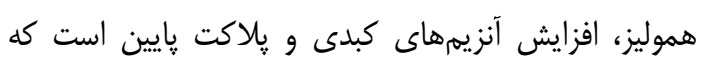
يك اورزانس بوده و بايد به باردارى خاتمه داد.

بررسىهاى آزمايشخاهى: شامل آناليز ادرار، شمارش

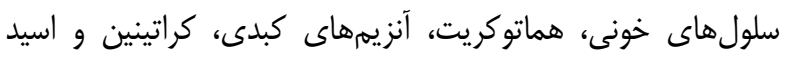

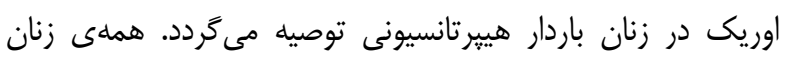

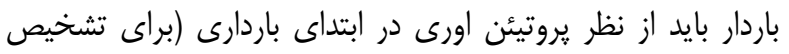

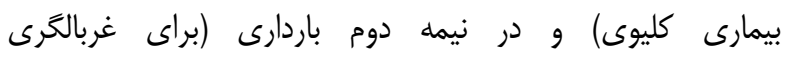

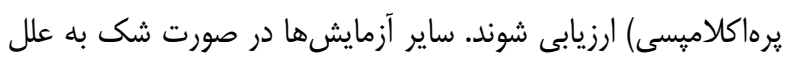

$$
\text { ثانويه درخواست مى شود. }
$$

بيشَّيرى از يره اكلاميسى

|

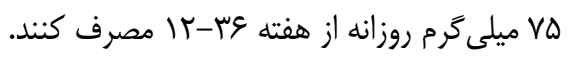

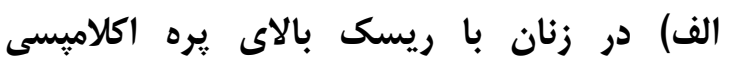

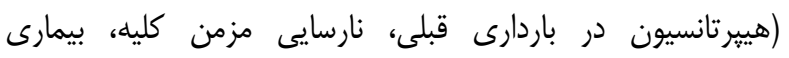

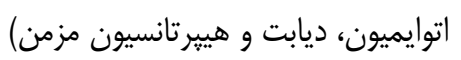
ب) در زنان با ريسك متوسط يره اكلاميسى (اولين

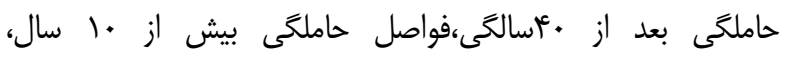

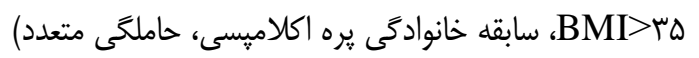
r-مصرف كلسيم خوراكى: در صورت كمبود كلسيم مصرفى در رزيم غذايى (كمتر از ..9 ميلى

$$
\text { هيير تانسيون در باردارى }
$$

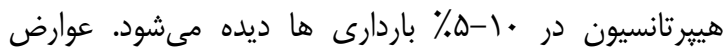

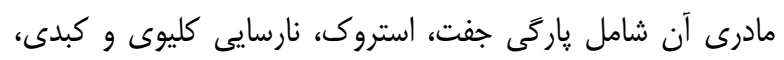
انعقاد منتشر داخل عروقى (DIC) و عوارض ان ماءرل باركى جنينى آن شامل كاهش رشد داخل رحمى، تولد زودرس، مرك داخل رحمى مى باشد.

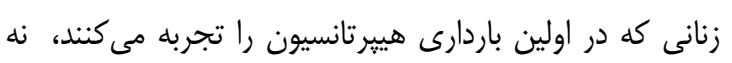

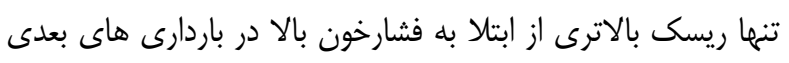

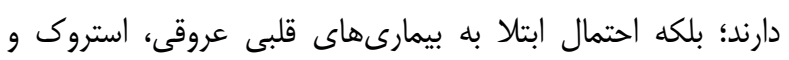

$$
\text { هيير تانسيون در آينده را نيز دارند. }
$$

فشارخون بايد در باردارى در حالت نشسته و(در حين زايمان در

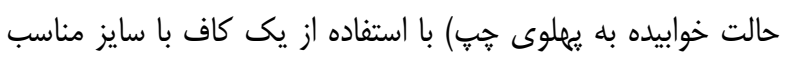

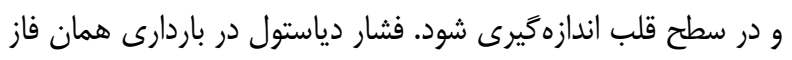

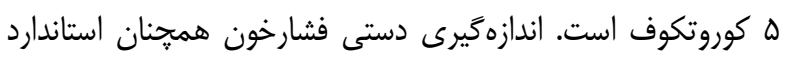

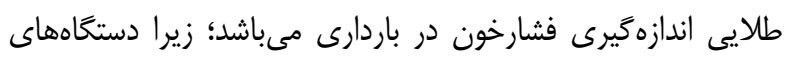
اتوماتيك ممكن است باعث ثبت فشارخون كمتر از حد واقعى شود.

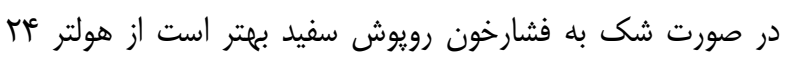
ساعته فشارخون استفاده شود (ᄉ).

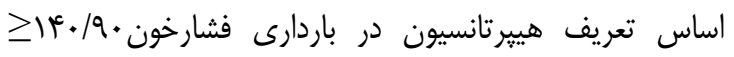

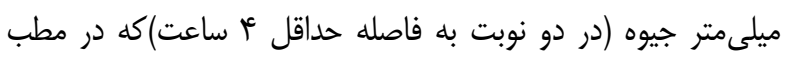

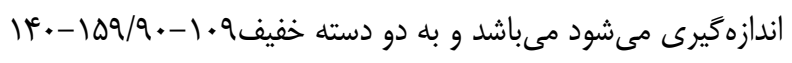

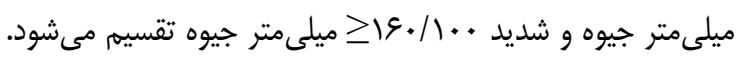

$$
\text { انواع فشارخون بالا در دوران باردارى }
$$

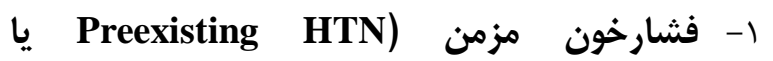

Chronic HTN

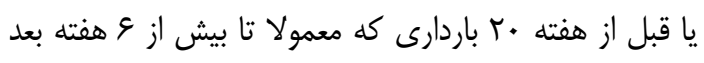
از زايمان باقى مى ماند و ممكن است با يروتيئن اورى همراه

باشد.

r- فشارخون باردارى (Gestational HTN): ايجاد

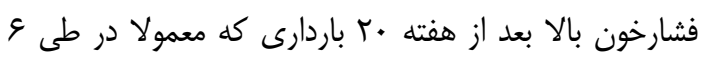
هفته بعد از زايمان برطرف مىشود.

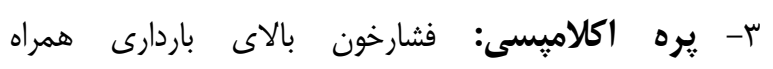


منيزيم داخل وريدى براى بيشخيرى از اكلامبسى و تشنج

$$
\text { توصيه مىشود. }
$$

צ- درصورت ادم حاد ريه درمان با نيتروكليسيرين وريدى تا حداكثر دوز •.1 ميكروكرم در دقيقه توصيه مىشود؛ امّا نيترويروسايد

$$
\text { بخاطر خطر مسموميت جنين با سيانيد ممنوع است. }
$$

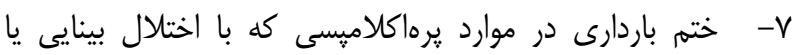

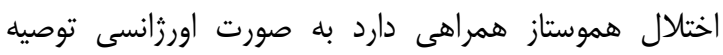

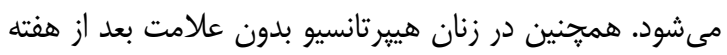

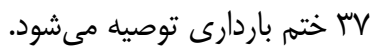
1- - در مورد عدد هدف فشارخون (Target BP) در زنان باردار

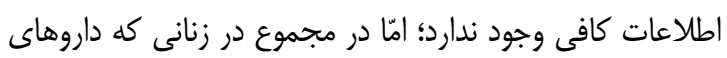

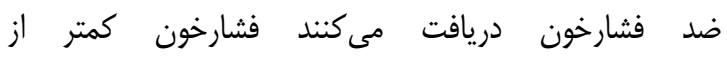

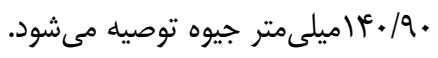

\section{هيبر تانسيون در شيردهى}

افزايش فشارخون در هفته اول پِ از زايمان شايع است. تمام داروهاى ضد فشارخون كه مادر استفاده مى كند در شير ترشح مىشود كه اغلب آنها غلظت خيلى كمى در شير دارند. از مصرف مار مارد

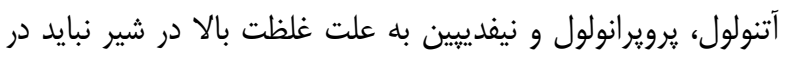

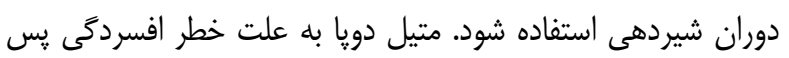

$$
\text { از زايمان توصيه نمى شودد. }
$$

\section{هيبر تانسيون در افراد مسن}

شيوع فشارخون با افزايش سن افزايش مىيابد؛ به طورى كه

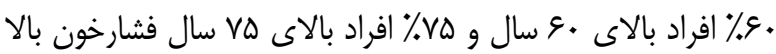

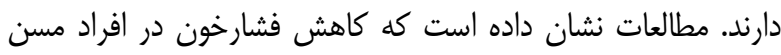
باعث كاهش موربيديتى و مورتاليتى ناشى از بيمارىهاى قلبى

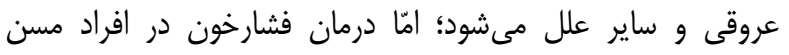
جالش بزرگى است. از يك سو اين بيماران بيمارىهاى همراه

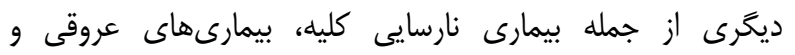
هييوتانسيون ارتواستاتيك دارند كه اين عوامل با مصرف دارئل داروهاى

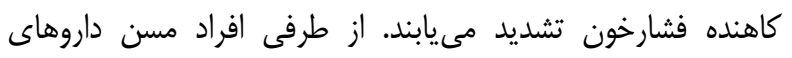

فرد روزانه ץ-ه/ آ كرم كلسيم مصرف نمايد.

\section{نكات مهم درمان دارويى در فشارخون حاملكى}

هدف از درمان دارويى فشارخون در باردارى كاهش عوارض دور دوريس مربوط به مادر است.

درمان دارويى در فشارخون باردارى موارد زير توصيه مىشوند: 1- در همه زنان در فشارخون بيشتر از هو/•ها ميلىمترجيوه دارو شروع شود. r- در فشارخون باردارى با يا بدون يروتيئن اورى، فشارخون مزمن

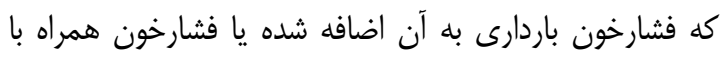

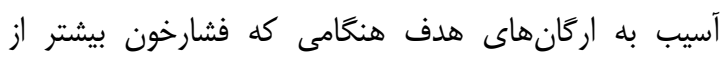

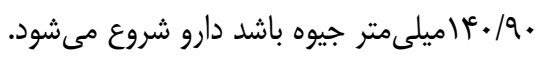

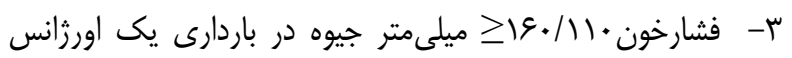

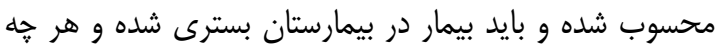

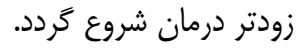

\section{داروهاى مصرفى در باردارى}

ו- در فشارخون مزمن به جز داروهاى ACE inhabitor، و و مهاركنندههاى مستقيم رنين كه منع مصرف دارند، ساير داروهاى ضد فشارخون را مىتوان ادامه داد.

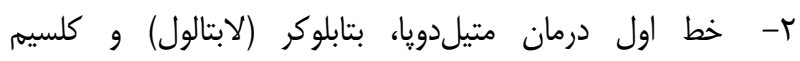
بلوكرهاى دى هيروييريدن (نيفدييين، نيكاردييين) هستند. r- بتابلوكرها ممكن است باعث ايجاد برادى كاردى جنينى شوند

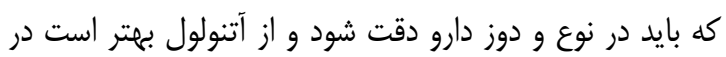
باردارى يرهيز شود. ץ- ديورتيكها (بهدليل كاهشى كه در حجم קپاسما ايجاد مى كنند) توصيه نمى شوند.

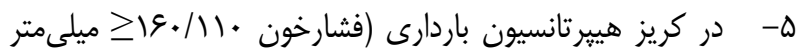
جيوه) بيمار بايد بسترى شده و درمان وريدى با لابتالول داخل

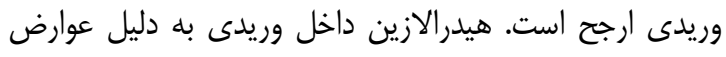

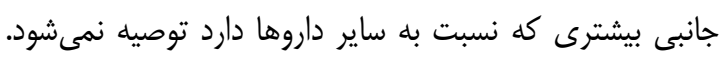

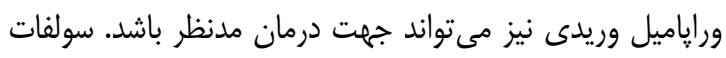


يزشكان است كه كنترل آن نقش بسيار مؤثرى در يِيشگيرى از

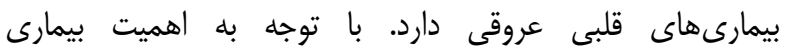

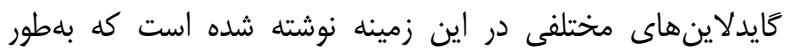

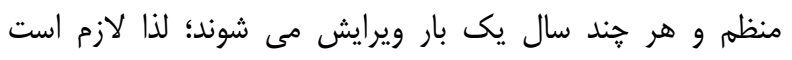

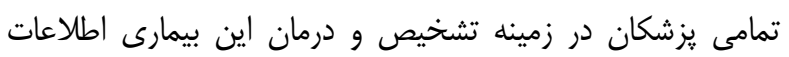
خود را به روز نغَه دارند.

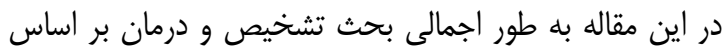

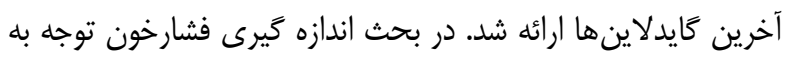

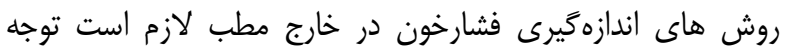

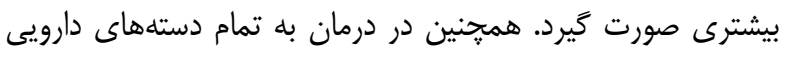

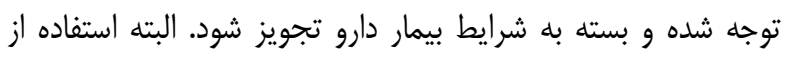

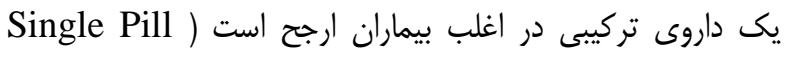

.Combination

ACCB ARB ACEI هستند. مطالعات حاكى از آن است كه استفاده از بتابلوكرها به عنوان

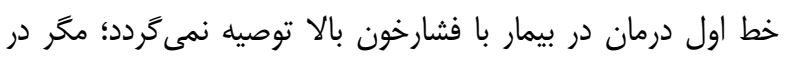

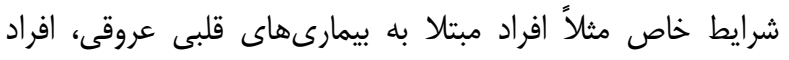
جوان با تاكيكاردى، اضطراب و غيره.

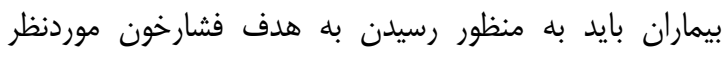
درمان شوند. براى اكثر بيماران مبتلا به فشارخون بالا، فشارخون

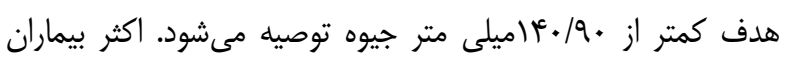

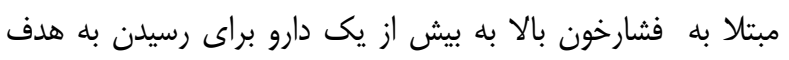

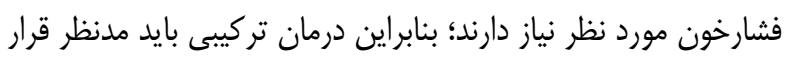
گيرد. بهينهسازى درمان فشارخون از راه هاى مختلفى امكان يذير است. رويكردهاى تيم محور براى رسيدن به فشارخون هدف مؤثر

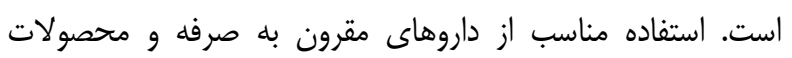

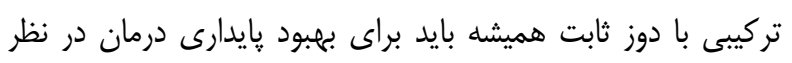

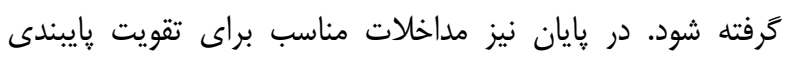

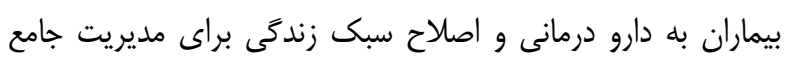
فشار خون بالا مورد نياز است.

تقدير و تشكّر نويسندكان مقاله از همكارى پايحاه توسعه تحقيقات بالينى
متعددى مصرف مى كنند كه اين داروها مىتواند بر روى فشارخون اثر كذاشته و يا با داروهاى كاهنده فشارخون تداخل داشته باشند. درمان فشارخون در افراد مسن (9Q 9D-V9 سال) مشابه ساير

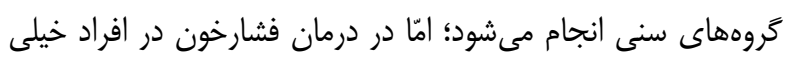
مسن (بيش از •م سال) نياز به دقت نظر دارد. در اين بيماران بايد

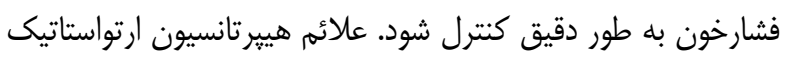

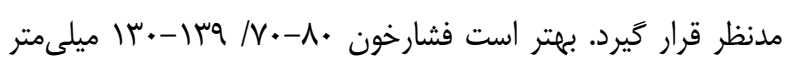

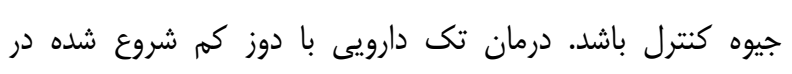

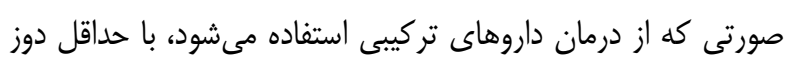

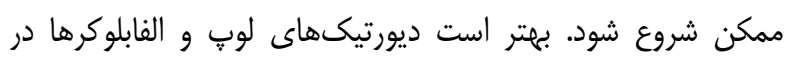
افراد مسن بدليل خطر سقوط و حوادث ناشى از آن تجويز نشود.

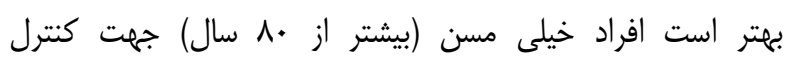
فشارخون به يك مركز تخصصى ارجاع شوند (^).

\section{هيبر تانسيون در بيمار ان مبتلا به كرونا}

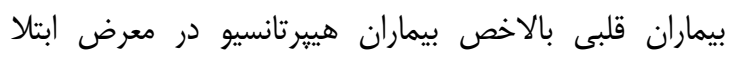

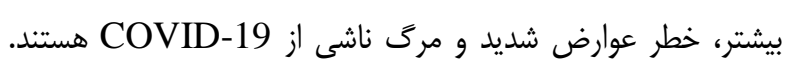
رفتار ويروس كرونا در بيمارن هيبرتانسيو بسيار متفاوت است. در خرد

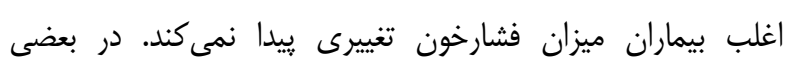

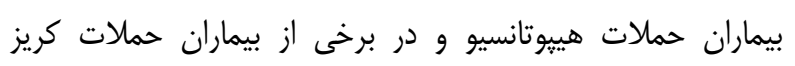

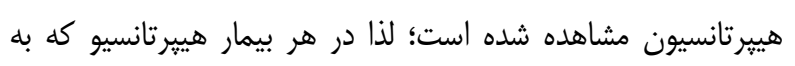

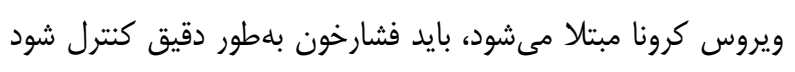

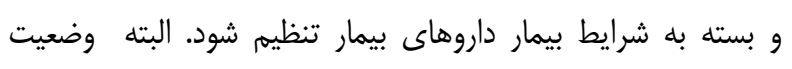
الكتروليتهاى سرم بالاخص يتاسيم مد نظر قرار داشته باشد.

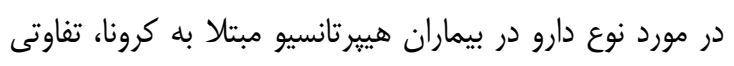

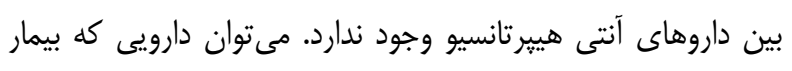
قبلا استفاده مىكرده را ادامه داد. در مورد داروهاى مهار كنتنده

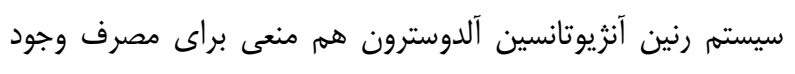

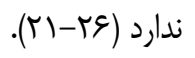

\section{نتيجه}

هييرتانسيون يكى از علل شايع مراجعه به كلينيك و مطب 


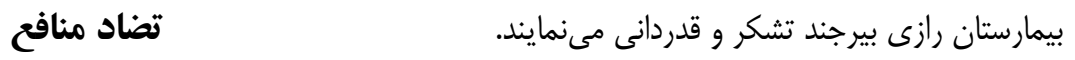

$$
\begin{aligned}
& \text { نويسندكان مقاله اعلام مى دارند كه هيج كَونه تضاد منافعى در } \\
& \text { يزوهش حاضر وجود ندارد. }
\end{aligned}
$$

1- Rezaianzadeh A, Jafari F, Sadeghi SE, Rahimikazerooni S. The prevalence and predictors of pre-hypertension and hypertension in Kherameh cohort study: a population based study on 10,663 persons in south of Iran. J Hum Hypertens. 2021; 35(3): 257-264. DOI: 10.1038/s41371-020-0330-8.

2- Panahi MH, Mahdavi Hezaveh AR, Samavat T, Hodjatzadeh A, Yousefi E. Hypertension Surveillance in Rural Regions of Iran. Iran J Public Health. 2019; 48(12): 2313-4. Link

3- Kazemi T, Nik M. "World heart day 2014", Significance of cardiovascular diseases in east of Iran. J Res Med Sci. 2015; 20(5): 423 . DOI: 10.4103/1735-1995.163950

4- Kazemi T, Hajihosseini M, Mashreghimoghadam H, Azdaki N, Ziaee M. Prevalence and determinants of hypertension among Iranian adults, Birjand, Iran. Int J Prev Med. 2017; 8:36. DOI: 10.4103/ijpvm.IJPVM_103_16

5- Kazemi T, Tavakoli T, Hajihosseini M, Yari E. Prevalence of Pre-hypertension and Risk Factors in an Iranian Population: East of Iran. Int Cardio Res J. 2018; 12(1):e10335. Link

6- Azdaki N, Kazemi T. National project of blood pressure control: Do's and don't's.J Birjand Univ Med Sci. 2019; 26(2): 95-7. DOI: 10.32592/JBirjandUnivMedSci.2019.26.2.100

7- Whelton PK, Carey RM, Aronow WS, Casey DE, Collins KJ, Himmelfarb CD, et al. 2017 ACC/AHA/AAPA/ABC/ACPM/AGS/APhA/ASH/ASPC/NMA/PCNA guideline for the prevention, detection, evaluation, and management of high blood pressure in adults: a report of the American College of Cardiology/American Heart Association Task Force on Clinical Practice Guidelines. Hypertension. 2018; 71(6): 1269-1324. DOI: 10.1161/HYP.0000000000000066

8- Williams B, Mancia G, Spiering W, Agabiti Rosei E, Azizi M, Burnier M, et al. 2018 ESC/ESH Guidelines for the management of arterial hypertension: The Task Force for the management of arterial hypertension of the European Society of Cardiology (ESC) and the European Society of Hypertension (ESH). J Hypertens. 2018; 36(10): 19532041. DOI: $10.1097 /$ HJH.0000000000001940

9- Bakris G, Ali W, Parati G. ACC/AHA versus ESC/ESH on hypertension guidelines: JACC guideline comparison. J Am Coll Cardiol. 2019; 73(23): 3018-26. DOI: 10.1016/j.jacc.2019.03.507

10- Unger T, Borghi C, Charchar F, Khan NA, Poulter NR, Prabhakaran D, et al. 2020 International Society of Hypertension global hypertension practice guidelines. Hypertension. 2020; 75(6): 1334-57. DOI: 10.1161/HYPERTENSIONAHA.120.15026

11- Freeman R, Illigens BM, Lapusca R, Campagnolo M, Abuzinadah AR ,Bonyhay I, et al. Symptom Recognition Is Impaired in Patients With Orthostatic Hypotension. Hypertension. 2020; 75(5): 1325-32. DOI: 10.1161/HYPERTENSIONAHA.119.13619

12- Song BM, Kim HC, Shim J-S, Kang DR. Comparison between right and left upper arms in detection of hypertension. Korean Circ J. 2019; 49(3): 267-77. DOI: 10.4070/kcj.2018.0147

13- Muntner P, Einhorn PT, Cushman WC, Whelton PK, Bello NA, Drawz PE, et al. Blood pressure assessment in adults in clinical practice and clinic-based research: JACC scientific expert panel. J Am Coll Cardiol. 2019; 73(3): 317-35. DOI: 10.1016/j.jacc.2018.10.069 
14- Etyang AO, Sigilai A, Odipo E, Oyando R, Ong'ayo G, Muthami L, et al. Diagnostic accuracy of unattended automated office blood pressure measurement in screening for hypertension in Kenya. Hypertension. 2019;74(6):1490-98. DOI: 10.1161/HYPERTENSIONAHA.119.13574

15- Victor RG, Li N, Blyler CA, Mason ONR, Chang LC, Moy NPB, et al. Nocturia as an unrecognized symptom of uncontrolled hypertension in black men aged 35 to 49 years. J Am Heart Assoc. 2019; 8(5): e010794. DOI: 10.1161/JAHA.118.010794

16- Goldmann E, Roberts ET, Boden-Albala B. Abstract P190: Hypertension, Hypertension Awareness and Depressive Symptom Severity in a Large Hispanic Population. Circulation. 2017; 135(suppl_1): AP18. DOI: 10.1161/circ.135.suppl_1.p189

17- Krause I, Cleper R, Kovalski Y, Sinai L, Davidovits M. Changes in behavior as an early symptom of renovascular hypertension in children. Pediatr Nephrol. 2009; 24(11): 2271-4. DOI: 10.1007/s00467-009-1205-y

18- Naseh G, Fard MM, Kazemi T, Mirgholami A, Hashemi N, Saburi A. Comparison of carotid intima-media thickness in hypertensive patients and control group. J Cardiovasc Echogr. 2016; 26(2): 48-51. DOI: 10.4103/22114122.183749

19- Takasaki K, Miyata M, Imamura M, Yuasa T, Kuwahara E, Kubota K, et al. Left ventricular dysfunction assessed by cardiac time interval analysis among different geometric patterns in untreated hypertension. Circ J. 2012; 76(6): 1409-14. DOI: 10.1253/circj.cj-11-1369

20- Jones NR, McCormack T, Constanti M, McManus RJ. Diagnosis and management of hypertension in adults: NICE guideline update 2019. Br J Gen Pract. 2020 Feb 1;70(691):90-1. DOI: 10.3399/bjgp20X708053

21- Tang S, Brady M, Mildenhall J, Rolfe U, Bowles A, Morgan K. The new coronavirus disease: what do we know so far? Journal of Paramedic Practice (JPP). 2020; 12(5): 193-201. DOI: 10.12968/jpar.2020.12.5.193

22- Kai H, Kai M. Interactions of coronaviruses with ACE2, angiotensin II, and RAS inhibitors-lessons from available evidence and insights into COVID-19. Hypertens Res. 2020; 43, 648-654. DOI: 10.1038/s41440-020-0455-8

23- Cardiology ESo. Position statement of the ESC Council on Hypertension on ACE-inhibitors and angiotensin receptor blockers. ESC. 2020.

24- Ren L, Yu S, Xu W, Overton JL, Chiamvimonvat N, Thai PN. Lack of association of antihypertensive drugs with the risk and severity of COVID-19: a meta-analysis. J Cardiol. 2021; 77(5): 482-91. DOI: $10.1016 /$ j.jjcc.2020.10.015

25- Du Y, Zhou N, Zha W, Lv Y. Hypertension is a clinically important risk factor for critical illness and mortality in COVID-19: A meta-analysis. Nutr Metab Cardiovasc Dis. 2021; 31(3): 745-55. DOI: 10.1016/j.numecd.2020.12.009

26- Sheppard JP, Nicholson BD, Lee J, McGagh D, Sherlock J, Koshiaris C, et al. Association between blood pressure control and coronavirus disease 2019 outcomes in 45418 symptomatic patients with hypertension: an observational cohort study. Hypertension. 2021; 77(3): 846-55. DOI: 10.1161/HYPERTENSIONAHA.120.16472 